\title{
edoc
}

Institutional Repository of the University of Basel

University Library

Schoenbeinstrasse 18-20

CH-4056 Basel, Switzerland

http://edoc.unibas.ch/

Year: 2014

\section{Functional crosstalk of PGC-1 coactivators and inflammation in skeletal muscle pathophysiology}

\author{
Eisele, Petra S. and Handschin, Christoph
}

Posted at edoc, University of Basel

Official URL: http://edoc.unibas.ch/dok/A6223606

Originally published as:

Eisele, Petra S. and Handschin, Christoph. (2014) Functional crosstalk of PGC-1 coactivators and inflammation in skeletal muscle pathophysiology. Seminars in immunopathology, Vol. 36, no. 1. S. 27-53. 
Review in Seminars in Immunopathology on "Metabolic Syndrome" (01/2014)

\section{Functional crosstalk of PGC-1 coactivators and inflammation in skeletal muscle} pathophysiology

Petra S. Eisele ${ }^{1}$, Christoph Handschin ${ }^{1}$

${ }^{1}$ Biozentrum, University of Basel, Klingelbergstrasse 50/70, CH-4056 Basel, Switzerland

Published in Semin Immunopathol. 2014 Jan;36(1):27-53. PMID: 24258516. doi: 10.1007/s00281013-0406-4

Copyright (C) Springer; Seminars in Immunopathology 


\title{
Functional crosstalk of PGC-1 coactivators and inflammation in skeletal muscle pathophysiology
}

\author{
Petra S. Eisele ${ }^{1}$, Christoph Handschin ${ }^{1}$
}

${ }^{1}$ Biozentrum, University of Basel, Klingelbergstrasse 50/70, CH-4056 Basel, Switzerland

To whom correspondence should be addressed: Christoph Handschin, phone: +41 61267 2378, fax +41612672208, email: christoph.handschin@unibas.ch

\begin{abstract}
(150 - 250 words) [165]
Skeletal muscle is an organ involved in whole body movement and energy metabolism with the ability to dynamically adapt to different states of (dis-)use. At a molecular level, the peroxisome proliferatoractivated receptor $\gamma$ coactivators 1 (PGC-1) are important mediators of oxidative metabolism in skeletal muscle and in other organs. Musculoskeletal disorders as well as obesity and its sequelae are associated with PGC-1 dysregulation in muscle with a concomitant local or systemic inflammatory reaction. In this review, we outline the function of PGC-1 coactivators in physiological and pathological conditions as well as the complex interplay of metabolic dysregulation and inflammation in obesity with special focus on skeletal muscle. We further put forward the hypothesis that in this tissue, oxidative metabolism and inflammatory processes mutually antagonize each other. The nuclear factor $\kappa \mathrm{B}(\mathrm{NF}-\kappa \mathrm{B})$ pathway thereby plays a key role in linking metabolic and inflammatory programs in muscle cells. We conclude this review with a perspective about the consequences of such a negative crosstalk on the immune system and the possibilities this opens for clinical applications.
\end{abstract}

\section{Keywords}

Skeletal muscle, metabolism, metabolic disorders, inflammation, PGC-1, NF- $\mathrm{B}$, macrophages 


\section{Introduction}

Obesity has become a global epidemic and a large number of deaths can be attributed to obesity-related disorders commonly known as the "metabolic syndrome". Understanding the molecular mechanisms underlying this syndrome is crucial to be able to develop appropriate treatment strategies and improve quality of life of patients. Skeletal muscle is important in glucose homeostasis as a large part of blood glucose is taken up into this tissue, stored as glycogen or used as substrate. Skeletal muscle insulin resistance is thus detrimental as it disturbs whole body glucose metabolism. The development of insulin resistance is closely linked to inflammation, which has been studied extensively in white adipose tissue. Macrophages and other cells of the immune system interact with cells of the resident tissue to promote or restrain inflammatory reactions. This fosters or impedes the genesis of insulin resistance, respectively. In skeletal muscle, these processes and their interdependence have just started to be elucidated.

PGC-1 coactivators are transcriptional coregulators that facilitate expression of an oxidative metabolic program in energy-demanding organs including skeletal muscle, in particular in adaptation to endurance training. Many skeletal muscle pathologies, for example muscle wasting, are associated with PGC-1 repression and accompanied by inflammatory reactions in muscle tissue. PGC-1 downregulation has also been observed in skeletal muscle of diabetic patients that display higher levels of pro-inflammatory cytokines both in muscle and blood, a situation that is recapitulated in mice that lack PGC-1 $\alpha$. Inversely, exercise is known to promote anti-inflammatory effects and PGC-1 coactivators recently have been shown to have anti-inflammatory properties in vitro.

In the current review, we therefore examine the influence of inflammation on PGC-1 coactivators and vice versa focusing on skeletal muscle. We provide thorough background information on all the relevant areas including skeletal muscle physiology and pathology, PGC-1 coactivator regulation and function and the molecular basis of inflammatory reactions. We then explore how oxidative metabolism and inflammatory processes are linked providing evidence for a mutual, negative regulation. This antagonism has far reaching consequences both for muscle and immune cells, positioning skeletal muscle at the cross road of metabolic and inflammatory processes.

\section{$1 \quad$ Skeletal muscle}

\subsection{Skeletal muscle structure and function}

The human body contains different types of muscle, mainly skeletal muscle, cardiac muscle and smooth muscle that all have the ability to contract. While cardiac and smooth muscle contraction is involuntary, skeletal muscle contraction can be controlled deliberately as it contributes fundamentally to locomotion and posture.

To fulfill these purposes, skeletal muscle is attached to the bone by tendons, enveloped by a layer of connective tissue (the epimysium) and organized in several functional units. The largest unit is the muscle bundle. Each skeletal muscle comprises several bundles, so-called fasciculi, which are confined by the perimysium, another layer of connective tissue. The second functional unit is the myofiber, a postmitotic, syncytial muscle cell, itself lined by connective tissue (the endomysium). Multiple myofibers run in parallel to form a bundle. Each myofiber contains numerous myofibrils, the smallest functional unit of skeletal muscle. Myofibrils are linear sequences of sarcomers, which are the fundamental contractile element of muscle cells. Under the microscope, these sarcomere repeats appear as distinct bands giving skeletal muscle its unique, striated pattern. At a molecular level, 
sarcomers are composed of the interdigitating myofilaments myosin and actin, which contract by sliding along each other and thereby shorten the muscle [1].

Skeletal muscles are innervated by motor neurons, which originate in the spinal cord. The synapse between motor neuron and muscle constitutes the neuromuscular junction. One motor neuron and all muscle fibers that are innervated by this neuron are called a motor unit. All fibers of a motor unit always contract in conjunction upon excitation of the innervating motor neuron. This excitation manifests in an action potential which leads to release of the neurotransmitter acetylcholine into the synaptic cleft at the neuromuscular junction. Postsynaptically, acetylcholine binds to its receptor, a ligand-gated ion-channel, and evokes an end plate potential by depolarization. This potential propagates along the fiber membrane (sarcolemma) which has deep invaginations (transverse tubules) harboring voltage-gated dihydropyridine receptors. These receptors in turn activate ryanodine receptors in the adjacent sarcoplasmic reticulum (SR) leading to a release of calcium from this compartment. Increased intracellular calcium concentrations finally initiate contraction. The close proximity of dihydropyridine receptors in the sarcolemma of transverse tubules and ryanodine receptors in the SR enables excitation-contraction coupling [1].

Contraction requires the binding of myosin to actin filaments. In the basal state, the binding sites (active sites) are however masked by the troponin-tropomyosin complex thus hindering interactions. Binding of calcium to troponin exposes the active sites and enables myosin heads to form cross bridges which subsequently move, hence sliding the myofilaments against one another. The cross bridges are released by binding of ATP allowing another cycle of contraction. Contraction ends when calcium is pumped back to the SR and no further actin-myosin interactions occur [1].

\subsection{Metabolic characteristics of skeletal muscle}

Myosin filaments in skeletal muscle contain six subunits, two heavy chains and four light chains, whereby different types of myosin heavy chains (MHC) can be distinguished. They vary in their contractile characteristics and are prototypical for different types of muscle fibers, which are adapted to different kinds of contraction. Type I or slow fibers that contain MHC I contract with low maximal force but are highly resistant to fatigue while type II or fast fibers that contain MHC II fatigue rapidly but are able to produce a high maximal force. Type I fibers appear red due to a high level of vascularization while type II fibers appear white. The latter can be further subdivided into type IIa (moderately fast), type IIx (intermediate) and type IIb (very fast) fibers. According to their contraction properties, the various fiber types primarily rely on different metabolic pathways as energy source: while type I and IIa fibers are oxidative, type IIx and IIb fibers are glycolytic [1].

Glycolytic fibers mainly metabolize glucose, which is taken up into muscle cells by glucose transporters (GLUT), some of which translocate to the membrane upon higher energy demand. In the cytosol, glucose is then converted into pyruvate by glycolysis producing ATP via substrate-level phosphorylation. As glycolytic fibers contain few mitochondria, pyruvate is further transformed anaerobically into lactic acid recovering the pool of $\mathrm{NAD}^{+}$, an essential cofactor of glycolysis [2]. This process enables very fast supply of energy for intensive bursts of work, however only for limited periods of time. Type II muscle fibers are thus typical for strength athletes.

At the other end of the spectrum, oxidative fibers contain a high number of mitochondria, which are the main site of aerobic energy production. The mitochondrial matrix harbors enzymes of fatty acid $\beta$ oxidation and the citric acid cycle while the mitochondrial inner membrane comprises the components of the electron transport chain. Fatty acids are the main energy substrate of oxidative fibers besides glucose. They are taken up into muscle cells by fatty acid translocase CD36, activated in the cytosol and shuttled into mitochondria as acylcarnitines. Fatty acid $\beta$ oxidation then generates 
acetyl-CoA that is fed into the citric acid cycle producing NADH, which serves as electron donor of the electron transport chain (complex I-IV) with oxygen being the final acceptor. The energy liberated during the electron passage is stored as an electrochemical proton gradient across the inner mitochondrial membrane and ultimately dissipated by the ATP synthase that drives aerobic ATP production [2].

ATP fuels muscle contraction because it enables the release of myosin-actin interaction which is a prerequisite for the subsequent contraction cycle whereas ATP depletion results in muscle fatigue and the inability to sustain performance. In addition, ATP is required for various other processes that are important for muscle contraction, for example ATP-driven re-uptake of calcium into the SR. The availability and utilization of energy substrates is therefore vital for continuous contraction. As oxidative metabolism in type I muscle fibers is well-adapted to prolonged periods of intermediate workloads, these fibers are characteristic for endurance athletes.

\subsection{Obesity-related changes in skeletal muscle}

Skeletal muscle is the main site of glucose disposal in the body and therefore contributes substantially to whole-body glucose homeostasis. In metabolic diseases, glucose homeostasis becomes dysregulated resulting in hyperglycemia due to elevated levels of hepatic gluconeogenesis and diminished levels of glucose uptake into target tissues like skeletal muscle and fat. The deficit in glucose uptake stems from progressive insulin resistance of target tissues that precedes the exhaustion of insulin-producing pancreatic $\beta$ cells in type 2 diabetes [3].

Overnutrition raises free fatty acid levels in the circulation. Target cells including myocytes are unable to deal with the constant oversupply of lipids as it exceeds their capacities to oxidize fatty acids in mitochondria or store them as triglycerides. Therefore, lipid metabolites like diacylglycerol and ceramides accumulate within the cell. These lipids activate serine kinases, for example protein kinase $\mathrm{C}$ (PKC) that may phosphorylate insulin receptor substrate 1 (IRS1) at inhibitory serine residues [3]. In healthy muscle, IRS1 is phosphorylated at tyrosine residues upon insulin binding to its receptor. This in turn initiates phosphatidylinositol 4,5-bisphosphate 3-kinase (PI3K) and subsequent protein kinase B (PKB)/Akt activation, which finally phosphorylates GLUT4 leading to membrane translocation and glucose uptake into the cell. Inhibitory IRS1 serine phosphorylation in obesity blunts this signaling cascade as it prevents the required tyrosine phosphorylation events and therefore causes insulin resistance [3]. Indeed, intramyocellular lipid levels strongly correlate with insulin resistance. In non-diabetic subjects, insulin resistance initially may be compensated for by hyperinsulinemia in order to preserve normal glucose tolerance. Aggravated insulin resistance and $\beta$ cell dysfunction then mark the transition to overt type 2 diabetes where glucose tolerance is lost.

Mitochondria produce reactive oxygen species (ROS) as byproducts of cellular respiration when oxygen is reduced prematurely. The excess of fatty acids in skeletal muscle of obese patients and the associated overload of mitochondria leads to higher rates of ROS generation. Together with an insufficient ROS detoxification, this creates an environment of permanent oxidative stress [4]. Apart from the direct damage that ROS inflict upon macromolecules like DNA, proteins and lipids, oxidative stress also activates a number of cellular stress pathways including c-Jun N-terminal kinases (JNK) and p38/mitogen-activated protein kinases (MAPK) [4]. These serine kinases directly target IRS1 at inhibitory residues and thus bring about skeletal muscle insulin resistance. Furthermore, the nuclear factor $\kappa \mathrm{B}(\mathrm{NF}-\kappa \mathrm{B})$ pathway is redox-sensitive. Activation of JNK, p38/MAPK and NF- $\mathrm{BB}$ additionally induces transcription of inflammatory factors that substantially contribute to the development of insulin resistance. The exact role of inflammation in obesity and type 2 diabetes will be outlined below. 
The endoplasmic reticulum (ER) is responsible for synthesis, correct folding and secretion of proteins within the cell. It also plays an important role in calcium homeostasis, which is especially relevant in myocytes as calcium release from the SR initiates contraction. ER stress arises when this organelle is overburdened. Consequently, the unfolded protein response (UPR) acts as adaptive mechanism to resolve ER stress by reducing protein synthesis, increasing protein degradation and ER folding capacities through higher chaperone levels [5]. If chronically active, the UPR also induces NF$\kappa \mathrm{B}$ and JNK signaling, which both cause transcription of inflammatory factors and inhibitory IRS1 phosphorylation events leading to insulin resistance. ER stress may also heighten ROS levels, which again has a negative influence on insulin sensitivity.

The accumulation of lipid derivatives in skeletal muscle of obese patients leads to considerable ER stress, which is also evident in vitro when treating muscle cells with palmitate $[6,7]$. Tunicamycin-induced, profound ER stress dampens insulin action in myocyte cultures by evoking JNK and mammalian target of rapamycin (mTOR)/S6 kinase-1 (S6K1) signaling, which both target IRS1 serine residues [6]. Whether the same pathways are active in muscle cells treated with palmitate is less clear, however, and the contribution of ER stress to the development of insulin resistance under these conditions remains controversial [7].

\section{The PGC-1 family}

\subsection{Molecular characteristics of PGC-1 coactivators}

Transcription is a tightly regulated process that involves the binding of transcription factors to response elements in the promoter region of target genes. Those transcription factors subsequently attract chromatin remodeling enzymes and the RNA polymerase complex to the promoter in order to initiate transcription. Transcriptional activation is further fine-tuned by coregulators that either facilitate (coactivators) or hinder (corepressors) initiation.

The peroxisome proliferator-activated receptor (PPAR) $\gamma$ coactivator 1 (PGC-1) family comprises three members, PGC-1 $\alpha$, PGC- $1 \beta$ and PGC-1-related coactivator (PRC) that all act as transcription coactivators. Their common structure features an $\mathrm{N}$-terminal activation domain (AD), one or several LXXLL or LLXXL motifs (where L is leucine and X is any amino acid) that represent the interface for nuclear receptor (NR) binding, a serine-rich or arginine-/serine-rich domain, and a $\mathrm{C}$ terminal RNA recognition and splicing motif (Fig. 1). PGC- $1 \alpha$ and PGC- $1 \beta$ also contain an inhibitory domain of about 200 amino acids adjacent to the AD. Two glutamine-rich domains are further characteristic for PGC-1 $\beta$, while PRC has a unique proline-rich domain (Fig. 1)

The PGC-1 coactivators do not harbor a DNA binding domain, but interact with specific transcription factors and NRs. PGC- $1 \alpha$ was originally discovered as cofactor of PPAR $\gamma$ and thyroid hormone receptor (TR) [8]. Subsequent studies identified most NRs as PGC-1 $\alpha$ binding partners, including PPAR $\alpha$, PPAR $\beta / \delta$, liver X receptor (LXR), farnesoid X receptor (FXR), vitamin D receptor (VDR), constitutive androstane receptor (CAR), pregnane $\mathrm{X}$ receptor (PXR), estrogen receptor $\alpha$ $(E R \alpha)$, estrogen-related receptor $\alpha(E R R \alpha)$ and $E R R \gamma$, glucocorticoid receptor (GR), hepatic nuclear factor $4 \alpha(\mathrm{HNF} 4 \alpha)$, and retinoid X receptor (RXR) [9-20]. This interaction can be either constitutive or ligand-dependent and indeed, human PGC-1 $\alpha$ was identified in a screen for steroid-responsive genes [21]. PGC-1 $\alpha$ is further able to coactivate a number of non-NR transcription factors like forkhead box protein O1 (Fox O1), FoxO3a, nuclear respiratory factor 1 (NRF1), myocyte-specific enhancer factor 2A (MEF2A), and MEF2C [22-26]. They bind PGC-1 $\alpha$ via domains that are distinct from the LXXLL motifs. 
PGC-1 $\beta$ interacts with the NRs PPAR $\alpha, E R \alpha, E R R \alpha$ and ERR $\gamma$, the transcription factors sterol regulatory element-binding protein 1a (SREBP1a) and SREBP1c, and FoxA2 [27-33]. Finally, PRC is able to potentiate ERR $\alpha$ - and NRF1-dependent transcription [34, 35].

Mechanistically, after binding to NRs or transcription factors, the PGC-1 coactivators act as recruitment platform for protein complexes that further boost transcription. The details of this assembly have been explored meticulously for PGC- $1 \alpha$ : The AD interacts with the histone acetyltransferases (HATs) steroid receptor-1 (SRC-1) and cyclic AMP response element-binding protein (CREB) binding protein (CBP)/p300, which mediate decondensation of chromatin [36]. BRG1-associated factor 60a (BAF60a) tethers the chromatin remodeling switch/sucrose nonfermentable (SWI/SNF) complex to a central stretch within the PGC-1 $\alpha$ protein, while the C-terminal region binds the TR-associated protein (TRAP)/vitamin D receptor-interacting protein (DRIP) or Mediator complex that directly associates with the basal transcription machinery and thus contributes to preinitiation complex formation $[37,38]$.

The positive effect of PGC-1 coactivators on transcription can be abrogated by nuclear corepressors that compete for binding sites on NRs and thus displace the coactivators. Examples include small heterodimer partner (SHP), SHP interacting leucine zipper protein (SMILE), and dosage-sensitive sex reversal adrenal hypoplasia congenital critical region on $\mathrm{X}$ chromosome, gene 1 (DAX-1) [39-42]. Beyond the initiation of RNA polymerisation, PGC-1 $\alpha$ is also implicated in RNA processing via the RNA recognition and splicing domain at the C-terminus [43].

Several isoforms of PGC-1 coactivators are currently known (Fig. 1). Alternative splicing gives rise to NT-PGC-1 $\alpha$ (amino acids 1-270), and to PGC-1 $\beta$-a and PGC-1 $\beta$-b (differing in exon 11) while alternative promoter usage generates PGC-1 $\beta-1$ (comprising exon 1a) and PGC-1 $\beta-2$ (comprising exon 1a' and exon 1b) $[44,45]$. PGC-1 $\alpha$ can also be transcribed from either the proximal or the alternative promoter (about $13 \mathrm{~kb}$ upstream) resulting in expression of PGC-1 $\alpha-\mathrm{a} / \mathrm{PGC}-1 \alpha 1$ (proximal promoter, exon 1), PGC-1 $\alpha$-b/PGC-1 $\alpha 2$ (exon 1b'), PGC-1 $\alpha-\mathrm{c} / \mathrm{PGC}-1 \alpha 3$ (exon 1b') and PGC-1 $\alpha 4$ (exon 1b'), the last three all originating at the alternative promoter [46-48] (Fig.1). In skeletal muscle, PGC- $1 \alpha-\mathrm{b} / \mathrm{PGC}-1 \alpha 2$ and PGC- $1 \alpha-\mathrm{c} / \mathrm{PGC}-1 \alpha 3$ are involved in adaptations to endurance exercise while PGC- $1 \alpha 4$ mediates a hypertrophic response upon resistance training [47, 48].

\subsection{Regulation of PGC-1 $\alpha$ activity}

As PGC-1 coactivators are potent inducers of transcription, their activity and expression levels are tightly controlled within the cell. Post-translational modifications (PTMs) and intracellular signaling events are by far best-studied for PGC- $1 \alpha$ and will be outlined in the following sections.

Different transcription factors control the synthesis of PGC-1 $\alpha$ mRNA: CREB is a potent inducer of PGC-1 $\alpha$ expression in different tissues and binds to cAMP response elements (CRE) in the promoter region of PGC-1 $\alpha$ when phosphorylated by protein kinases [49]. In skeletal muscle, exercise-mediated calcium release activates calcium/calmodulin-dependent protein kinase type IV (CaMK IV), which targets CREB and thereby augments PGC-1 $\alpha$ transcription [50].

MEF2C and MEFD are able to bind to MEF2 sites in the PGC- $1 \alpha$ promoter and elevate PGC$1 \alpha$ expression. Free, cytosolic calcium not only activates CaMK IV in skeletal muscle but also the phosphatase calcineurin A (CnA), which boost the activities of MEF2C and MEF2D. These transcription factors are bound and coactivated by PGC-1 $\alpha$ at its own promoter constituting a positive, autoregulatory feed-forward loop [50]. Exercise also activates p38/MAPK, which participates in PGC$1 \alpha$ transcriptional regulation at two places: p38/MAPK phosphorylates both MEF2C/D and activating 
transcription factor 2 (ATF2), thereby facilitating their binding to the PGC-1 $\alpha$ promoter and further boosting transcription $[51,52]$. Direct PGC-1 $\alpha$ phosphorylation will be discussed below.

As a sensor of low energy levels in the cell, AMP-activated protein kinase (AMPK) is also activated upon muscle contraction and promotes PGC-1 $\alpha$ expression [53]. Another autoregulatory loop has been described for PPAR $\beta / \delta$ : PGC- $1 \alpha$ heightens both PPAR $\beta / \delta$ and its own expression by coactivating this NR at the PGC-1 $\alpha$ promoter [54]. PPAR $\alpha$ and PPAR $\gamma$ are part of similar autoregulatory mechanisms in other organs, which therefore appear to be a common strategy in the induction of PGC-1 $\alpha$ expression [54, 55].

Reciprocally, transcription of the PGC-1 $\alpha$ gene can be inhibited by several factors. In hepatocytes, insulin-stimulated Akt targets FoxO1, which as a result dissociates from the PGC-1 $\alpha$ promoter [56]. The recruitment of chromatin remodeling enzymes and transcription corepressors to the promoter also influences PGC-1 $\alpha$ expression levels. Binding of histone deacetylases (HDACs) like HDAC5 to MEF2 compromises transcription as does the presence of SHP and nuclear corepressor 1 (NcoR1) [57-59]. A more general mechanism of repression is hypermethylation of non-CpG nucleotides in the PGC-1 $\alpha$ promoter, which is caused by DNA methyltransferase 3B (DNMT3B) [60].

The second important aspect defining the transcriptional coactivator potential of PGC- $1 \alpha$ is the modulation of PTMs that regulate protein stability and the binding affinity to transcription factors. A number of PTMs of PGC-1 $\alpha$ have been reported, including phosphorylation, acetylation, methylation, GlcNAcylation, sumoylation and ubiquitination.

Kinases target several serine and threonine residues within the PGC- $1 \alpha$ protein. AMPK- and p38/MAPK-dependent phosphorylation stabilizes PGC-1 $\alpha$ and decreases the interaction with the repressor p160 myb binding protein (p160 mbp) [53, 61, 62]. As both kinases also affect PGC-1 $\alpha$ transcription, they have a dual effect involving an acute (phosphorylation) and a more sustained (expression) response. Similarly, PKA phosphorylates NT-PGC-1 $\alpha$, a short transcript variant of PGC$1 \alpha$, and at the same time CREB, again constituting a dual, positive mode of action [63]. Akt and glycogen synthase kinase $3 \beta$ (GSK3 $\beta$ ) both mediate inhibitory PGC- $1 \alpha$ phosphorylation events [64, 65]. Prior negative phosphorylation is also required for polyubiquitination of PGC- $1 \alpha$, which targets the protein for proteasomal degradation [66].

The acetylation status of PGC- $1 \alpha$ further affects its activity. Acetyltransferase general control of amino acid synthesis 5 (GCN5) acetylates PGC-1 $\alpha$ at multiple lysine residues thus rendering it inactive due to relocalisation to nuclear foci, while $\mathrm{NAD}^{+}$-dependent protein deacetylase sirtuin 1 (Sirt1) removes these inhibitory acetyl residues [67-69]. As Sirt1 and AMPK are both sensors of cellular energy status, they act in concert to coordinately activate PGC-1 $\alpha$ [70].

SUMOylation of PGC- $1 \alpha$ does not change its subcellular localization or stability, but presumably facilitates interaction with receptor-interacting protein 140 (RIP140), a known repressor of PGC-1 $\alpha[71,72]$. Finally, O-linked $\beta$-N-acetylglucosylation and arginine methylation of PGC-1 $\alpha$ contribute to sustained transcription activity of this coactivator [73, 74].

The multitude of PTMs is a result of the complex signaling network that converges on PGC$1 \alpha$. Uncovering mutual influences and resolving the chronology of events in different organs in greater detail remains to be done.

\subsection{Role of PGC-1 coactivators in oxidative metabolism and skeletal muscle function}

PGC-1 $\alpha$ orthologs are present in all vertebrates species, with $95 \%$ sequence homology between mouse and human, and a high degree of conservation in the AD and NR interaction domain $[21,75]$. In Drosophila, the PGC-1 homologue spargel is essential for mitochondrial gene expression 
and spargel mutants display respiration defects [76]. This fundamental role of PGC-1 coactivators in cellular respiration is conserved across species, redundant between all 3 family members and important in all tissues that express PGC- 1 coactivators. PGC- $1 \alpha$ and PGC- $1 \beta$ are primarily enriched in organs with high oxidative capacity like skeletal muscle, heart, brown adipose tissue (BAT), kidney, and brain whereas PRC is found ubiquitously $[8,27,35]$. Hence, it appears that the coordination of oxidative metabolism is the central property of the PGC-1 family.

Mitochondrial biogenesis is necessary to meet higher energy demands in a cell. This complex process requires transcription of nuclear genes, import of the resulting proteins into mitochondria, transcription of mitochondrial DNA and its replication. PGC-1 coactivators integrate these events in cooperation with nuclear transcription factors 1 (NRF-1), NRF-2 (also called GA-binding protein or GABP) and ERR $\alpha$ that induce nuclear-encoded mitochondrial genes like cytochrome c oxidase subunit 4 (COX IV), $\beta$-ATP synthase, and mitochondrial transcription factor A (Tfam) $[24,29,34,35$, 77]. In turn, Tfam governs transcription and replication of mitochondrial DNA.

PGC-1 $\alpha$ also induces NRF-1, NRF-2 and ERR $\alpha$ at the expression level [25, 78]. Further signal amplification occurs through NRF-2 and ERR $\alpha$, which boost their own and each others' transcription respectively, to promote mitochondrial biogenesis in biological switches [79].

Surprisingly however, mice with a global deletion of either PGC- $1 \alpha$ or PGC- $1 \beta$ are viable, fertile and do not show overtly deranged mitochondria [80-83]. Their ability to cope with different stress conditions (for example exposure to cold) is however grossly compromised. This indicates that PGC-1 coactivators are less required for basal mitochondrial function but are instrumental in orchestrating adaptations to environmental challenges.

Interestingly, the PGC-1 coactivators affect mitochondrial function in a specific manner. During electron transport, protons may leak over the inner mitochondrial membrane. Ectopic expression of PGC- $1 \alpha$ in muscle cells promotes this leakage to a larger extend than PGC- $1 \beta$ although their effect on respiration is comparable [84].

Mitochondrial biogenesis is accompanied by an increase in ROS production. To alleviate the resulting oxidative stress, PGC- $1 \alpha$ and PGC-1 $1 \beta$ enhance the expression of ROS detoxifying enzymes like glutathione peroxidise $1(\mathrm{GPx}-1)$ and mitochondrial superoxide dismutase [Mn], (Sod2). Accordingly, PGC-1 $\alpha$ acts neuroprotectively under oxidative stress conditions [85].

Higher rates of oxidative phosphorylation require elevated substrate supply. PGC-1 $\alpha$ and PGC-1 $\beta$ augment fatty acid oxidation by coactivating ERR $\alpha$ and PPAR $\alpha$ in a constitutive and a ligand-dependent manner, respectively, which propagates the expression of key enzymes of this process such as medium-chain specific acyl-CoA dehydrogenase (MCAD) [9, 17, 86]. In addition, PGC-1 $\alpha$ fosters peroxisome biogenesis, an organelle that catabolizes very long and branched chain fatty acids [87]. In summary, PGC-1 coactivators drive a whole program of oxidative metabolism to provide sufficient amounts of energy to the cell.

In skeletal muscle, PGC-1 $\alpha$ is abundant and particularly enriched in slow twitch, oxidative muscle fibers that contain a large number of mitochondria. Forced expression of PGC-1 $\alpha$ converts white muscles with mainly fast fibers into red muscles with properties of slow-twitch type I and IIa fibers while PGC-1 $\beta$ provokes a fiber type switch to type IIx fibers [88, 89]. In agreement with its role in oxidative myofiber determination, PGC- $1 \alpha$ is transiently induced in skeletal muscle after a single bout of endurance exercise and chronically elevated in endurance trained muscle both in rodents and humans [90-92].

Many, if not all major adaptations of skeletal muscle in response to endurance training are mediated by PGC-1 $\alpha$, which therefore represents an important point of convergence in the exercisetriggered signaling network. The formation of a larger proportion of oxidative fibers requires mitochondrial biogenesis, fatty acid uptake (e.g. by CD36) and oxidation (e.g. by MCAD) in the 
myocyte to ensure adequate substrate supply. All of these processes are coordinately regulated by PGC-1 $\alpha[93,94]$. PGC-1 $\alpha$ also augments GLUT4 expression in vitro and in vivo yielding higher glucose uptake into muscle cells $[26,94]$. Pyruvate dehydrogenase kinase 4 (PDK4) is induced concomitantly to promote fatty acid oxidation at the expense of glucose metabolism [95]. Excess glucose that cannot be diverted into glycolysis is consequently stored in the form of glycogen and funneled into the pentose phosphate pathway $[94,96,97]$. The resulting elevation of NADPH and the PGC-1 $\alpha$-mediated activation of fatty acid synthase boost de novo lipogenesis and thus increased storage of intramyocellular lipids that serve as energy substrate. Thereby PGC-1 $\alpha$ coordinates anabolic and catabolic metabolic pathways in skeletal muscle [98].

Elevated ROS are a byproduct of higher mitochondrial activity in contracting skeletal muscle. As ROS reinforce PGC-1 $\alpha$ expression, which contributes to ROS detoxification by raising enzymes like Sod2 (see above), this negative feed-back loop protects myocytes effectively from oxidative stress $[99,100]$.

Apart from metabolic fluxes within the cell, PGC-1 $\alpha$ also tightly links muscle and nerve by regulating neuromuscular junction genes and promoting acetylcholine receptors clustering at the motor end plate [101]. In addition, PGC-1 $\alpha$ tiggers a remodeling of calcium handling in muscle cells towards a slow fiber-type phenotype [102]. Finally, PGC-1 $\alpha$ further affects angiogenesis by potently inducing vascular endothelial growth factor (VEGF) expression to maintain nutrient and oxygen supply to muscles during sustained contractions $[103,104]$.

In combination, all of these PGC-1 $\alpha$-mediated changes functionally translate into a higher endurance capacity as observed in PGC-1 $\alpha$ skeletal muscle-transgenic mice whereas skeletal musclespecific deletion of PGC-1 $\alpha$ decreases performance $[96,105]$.

The regulation and function of PGC- $1 \beta$ is much less clear. For example, PGC- $\beta$ is not uniformly influenced by exercise. Nevertheless, when overexpressed in skeletal muscle, genes involved in oxidative phosphorylation and fatty acid oxidation are also upregulated by PGC-1 $\beta$ resulting structurally in a higher mitochondrial density and functionally in a better endurance performance [89]. Inversely, skeletal muscle-specific PGC-1 $\beta$ deletion causes lower endurance capacity [106]. A combined deficiency of PGC-1 $\alpha$ and PGC- $1 \beta$ in a global PGC- $1 \alpha$ and a musclespecific PGC-1 $\beta$ knockout background aggravates this phenotype displaying a very severe exercise deficit, strongly reduced oxidative capacity and mitochondrial structure and function derangements. However, fiber type determination is only slightly changed in these mice [106]. Similar to PGC-1 $\alpha$, PGC-1 $\beta$ was also shown to enhance angiogenesis [107]. It therefore appears that PGC- $1 \alpha$ and PGC-1 $\beta$ share some properties in skeletal muscle and can potentially compensate for one another in some cases. The role as "exercise factor" is however unique to PGC-1 $\alpha$ and such a clear physiological function has not been assigned to PGC-1 $\beta$ so far.

Aside from the regulation of endurance adaptations, PGC- $1 \alpha$ is a target of the myogenic regulatory factor $\mathrm{MyoD}$ in terminal muscle differentiation and plays a role in regulating circadian clocks in muscle $[108,109]$. Interestingly, MyoD itself is under the control of circadian transcription activators and their disruption perturbs muscle function as well as PGC- $1 \alpha$ and PGC-1 $1 \beta$ expression [110]. Further studies are needed to investigate the mutual dependencies of PGC-1 coactivators, MyoD and clock genes to define their contribution to skeletal muscle physiology.

\subsection{Other organ-specific functions of PGC-1 coactivators}

In addition to the regulation of oxidative metabolism, PGC-1 coactivators also execute an array of tissue-specific functions. In the liver, PGC-1 $\alpha$ is markedly upregulated in response to fasting 
and controls several important starvation pathways including gluconeogenesis and ketogenesis, [18, $22,49]$. PGC-1 $\alpha$ further governs hepatic heme, bile acid, selenoprotein $P$, and homocystein biosynthesis [111-114]. PGC-1 $\beta$ by contrast is central to lipid metabolism in the liver by inducing lipogenesis and the secretion of triglycerides/VLDL into plasma [31,33].

Cardiac PGC- $1 \alpha$ is augmented both in development when perinatally, fatty acids replace glucose as main source of energy, and in adult animals upon fasting. Lack of either PGC-1 $\alpha$ or PGC$1 \beta$ promotes heart failure under stress conditions while a PGC- $1 \beta$ cardiac deficiency combined with a global PGC-1 $\alpha$ gene ablation is lethal shortly after birth as those hearts are unable to mature [115118]. Inversely, cardiac PGC-1 $\alpha$ overexpression causes disturbances in the sarcomere structure leading to dilated cardiomyopathy [119]. PGC-1 coactivator levels are thus only protective within a certain window of expression.

PGC-1 $\alpha$ was originally discovered as thermogenic regulator in BAT induced by cold exposure [8]. BAT produces heat by uncoupled respiration whereas white adipose tissue (WAT) mainly stores energy in form of lipid droplets. Both PGC- $1 \alpha$ and PGC- $1 \beta$ are critical for adequate BAT function and participate in brown fat lineage determination $[118,120,121]$. Induction of PGC- $1 \alpha$ in WAT thus results in "browning" while PGC-1 $\alpha$ suppression favors a white adipocyte phenotype [122-125]. Accordingly, mice with an adipose tissue-specific deletion of PGC-1 $\alpha$ on high fat diet develop insulin resistance as the excess energy cannot be sufficiently dissipated [126].

In pancreas, both PGC-1 $\alpha$ and PGC-1 $1 \beta$ are involved in glucose-stimulated insulin secretion from $\beta$ cells; their contribution is however controversial as suppression and induction of insulin release have been reported $[32,127,128]$.

Both coactivators control mitochondrial density in nerve cells [129]. Neuroprotection through PGC-1 $\alpha$ was shown in the contexts of oxidative stress and amyotrophic lateral sclerosis whereas neurodegeneration is associated with a loss of PGC-1 $\alpha$ in various disorders including Huntington's and Alzheimer's disease [85, 130-132]. Consistently, global and brain-specific deletion models of PGC-1 $\alpha$ exhibit striatal degenerative lesions and increased susceptibility for other neurodegenerative events $[80,133]$.

PGC-1 $\alpha$ also plays a role in light damage-induced retinal regeneration and function and in chondrogenesis $[134,135]$. PGC-1 $\beta$ is further implicated in osteoclast activation and PRC has a nonredundant function in proliferative growth $[136,137]$.

\subsection{PGC-1 coactivators in skeletal muscle pathology}

Skeletal muscle exhibits considerable plasticity and adapts to different training regiments as well as disuse. While endurance exercise induces PGC-1 $\alpha$ as described above, different experimental or pathological muscle wasting conditions like denervation-induced atrophy, statin treatment, diabetes, uremia, and cancer cachexia, reduce PGC-1 $\alpha$ and/or PGC-1 $\beta$ levels [138-141]. Accordingly, ectopic expression of PGC- $1 \alpha$ or PGC- $1 \beta$ counteracts the atrophic state by suppressing atrogenes in vitro and in vivo [140-142]. PGC-1 coactivators are thus able to preserve muscle structure and function under unfavorable circumstances. This observation extends to sarcopenia (progressive muscle loss with age) as old mice with transgenic PGC-1 $\alpha$ expression in skeletal muscle show a higher degree of muscle integrity, improved mitochondrial function and better exercise performance than age-matched wildtype animals [100].

Several inherited disorders affect skeletal muscle function. Duchenne muscular dystrophy (DMD) is caused by a mutation in dystrophin. Mutated dystrophin fails to link the cytoskeleton to the extracellular matrix leading to muscle degeneration and premature death. Mitochondrial myopathies stem from mutations in mitochondrial DNA. Skeletal muscle-specific overexpression of PGC-1 $\alpha$ is 
able to antagonize symptoms of both disorders in respective mouse models [101, 143]. PGC-1 $\alpha$ therefore dampens fiber damage and preserves muscle function in those contexts. A non-genetic approach deploying endurance training also raised PGC-1 $\alpha$ levels and protected mice with mitochondrial myopathy [144].

The etiology of Huntington's disease (HD) involves loss of muscle mass which coincides with a reduction of PGC-1 $\alpha$ expression in rodents and humans. This wasting phenotype could be improved by artificially increasing PGC-1 $\alpha$ levels in skeletal muscle [145].

Genetic and acquired obesity are strongly correlated with the development of insulin resistance and diminish both PGC-1 $\alpha$ and PGC-1 $\beta$ levels in rodent skeletal muscle [146]. In human diabetic patients, a coordinate suppression of genes involved in oxidative phosphorylation has been observed concomitant with a reduction of PGC-1 $\alpha$ and PGC-1 $\beta$ in some, but not all studies [147-149]. This suggests that dysregulated PGC-1 coactivator levels may account for disturbed energy metabolism in skeletal muscle contributing to the development of insulin resistance. Inversely, a moderate PGC-1 $\alpha$ increase in skeletal muscle improves insulin sensitivity through the selective elevation of fatty acid oxidation in subsarcolemmal, but not intermyofibrillar mitochondria [150].

The relationship between PGC-1 coactivators and insulin resistance is however more complex as two independent mouse strains lacking PGC-1 $\alpha$ are less susceptible to diet-induced obesity possibly owing to hyperactivity, which is likely a consequence of striatal brain lesions [80, 81]. Skeletal muscle-specific deletion models still display higher peripheral insulin sensitivity, however, they do become glucose intolerant on a high fat diet. This puzzling phenotype is the result of muscle-islet crosstalk whereby muscle-derived IL- 6 and possibly other factors might impair insulin secretion from pancreas leading to a deficit in glucose clearance from blood but at the same time to high insulin sensitivity in the periphery [151].

Surprisingly, muscle-specific PGC-1 $\alpha$ overexpressing animals develop insulin resistance at an accelerated pace on high fat diet compared to wild-type mice presumably due to excess lipid storage within muscle cells [152]. Interestingly, the same model is however protected from sarcopenia and preserves insulin signaling and sensitivity until old age [100]. In a twin study, PGC- $1 \alpha$ and PGC-1 $\beta$ emerged as factors declining with age which might contribute to an increased risk of diabetes in this phase of life [153]. Dropping PGC-1 $\alpha$ levels are associated with the common Gly482Ser variant but an unequivocal mechanistic link of this polymorphism to diabetes could not be established as the serine containing variant seems fully functional [154-156]. A polymorphism within the PGC-1 $\alpha$ promoter however clearly contributes to diabetes in Koreans and Austrians [157, 158].

PGC-1 $\beta$ protects mice from genetic and acquired obesity, but without effect on whole-body glucose metabolism or skeletal muscle insulin sensitivity [29, 82, 159]. Loss of function however promotes hepatic insulin resistance because of lipid accumulation in the liver [82, 159]. Yet, genetic linkage studies failed to prove a clear association of the Ala203Pro variant with obesity or diabetes $[160,161]$.

A PGC-1 $\alpha /$ PGC-1 $\beta$ double deficient model based on global PGC- $1 \alpha$ and muscle-specific PGC-1 $1 \beta$ gene ablation surprisingly is unaffected in terms of glucose or insulin tolerance on different diets. Importantly however, the global PGC-1 $\alpha$ deletion background confounds interpretation of these findings due to its complex brain phenotype [106].

Pharmacological treatment of mice with resveratrol protects them from diet-induced obesity and insulin resistance as Sirt1-dependent PGC-1 $\alpha$ activation stimulates oxidative metabolism in skeletal muscle $[162,163]$. Furthermore, the insulin-sensitizing properties of thiazolidinediones are at least partially ascribed to an induction of PGC- $1 \alpha$ and the concomitant restoration of mitochondrial bioenergetics in muscle e.g. in $\mathrm{db} / \mathrm{db}$ mice [164] 
Targeting PGC-1 coactivators in skeletal muscle to fight musculoskeletal and metabolic diseases and especially increase insulin sensitivity is therefore a worthwhile venture. There is however a therapeutic window for these beneficial effects as excessive PGC-1 coactivator levels may act counterproductive [165]. Dysregulation of these coactivators in other organs further complicate treatment as for example in liver and pancreas of diabetic patients PGC-1 $\alpha$ levels are increased which contributes to pathology in these tissues [165]. Finding potent and specific PGC-1 $\alpha$ and PGC-1 $\beta$ activators and inhibitors is thus of prime interest.

\section{$3 \quad$ Inflammation}

\subsection{Major molecular pathways in inflammation}

Inflammation is the protective response of the body to harmful insults like pathogens and wounding aiming at defense and repair to secure the organism's integrity. The immune system has evolved to govern these inflammatory reactions and comprises two branches, innate and adaptive immunity, respectively. The innate immune system is able to react rapidly and initiate an inflammatory reaction within minutes. The adaptive immune system operates secondarily and thus delayed, but is highly specific. Immune cells communicate with injured or infected cells and other immune cells via small, soluble peptides, so-called cytokines, that may elicit, potentiate or dampen inflammation and thus fundamentally influence its progression. Potent pro-inflammatory cytokines include the tumor necrosis factor $\alpha$ (TNF $\alpha$ ), interleukin $1 \beta$ (IL-1 $\beta)$, IL-6, and macrophage inflammatory protein $1 \alpha$ (MIP-1 $\alpha$ ) while IL-4, IL-10, IL-13 and IL-1 receptor antagonist (IL-1Ra) act primarily anti-inflammatory [166].

To transmit their signals, cytokines bind to cytokine receptors. These are grouped into different families according to their structure. Type I and type II cytokine receptors are multimeric transmembrane receptors that signal via the janus kinase (JAK) - signal transducers and activators of transcription (STAT) pathway while chemokine receptors are G protein-coupled receptors (GPCRs) with seven transmembrane domains that signal through G proteins. Members of the TNF receptor (TNFR) family oligomerize upon ligand binding. They are associated with adaptor proteins that may activate inflammatory or apoptotic pathways via TNFR associated factors (TRAFs) and the caspase cascade, respectively. The transforming growth factor $\beta$ (TGF $\beta$ ) receptor family has three members that connect to SMAD proteins. Finally, some cytokine receptors belong to the immunoglobulin (Ig) superfamily.

Pathogens contain conserved structures, so-called pathogen-associated molecular patterns (PAMPs) that can be recognized by the host's immune system to initiate inflammation. PAMPs bind to toll-like receptors (TLRs), which are expressed on the surface of immune and most other cells. So far, 12 mammalian TLRs with different binding specificities have been identified, e.g. TLR4 detecting lipopolysaccharide (LPS). TLRs signal through adaptor proteins like myeloid differentiation primary response gene 88 (Myd88) that further activate IL-1R-asscoiated kinases (IRAKs) and TRAFs finally leading to inflammation [167].

While STATs and SMAD proteins are able to translocate to the nucleus and modulate transcription of inflammatory genes directly, GPCR signaling typically leads to the production of second messengers. TRAF activation downstream of TNFRs and TLRs causes activation of the NF- $\kappa B$ pathway [167]. This pathway is central to inflammatory reactions and has been shown to be involved in a large number of diseases. NF- $\kappa \mathrm{B}$ activating signals converge at the inhibitor of $\kappa \mathrm{B}$ (I $\kappa \mathrm{B}$ ) kinase (IKK) complex which comprises three subunits, IKK $\alpha, \operatorname{IKK} \beta$ (both catalytic) and IKK $\gamma / \mathrm{NF}-\kappa \mathrm{B}$ essential modulator (NEMO, regulatory). Canonical NF- $\mathrm{KB}$ signaling involves activation of IKK, 


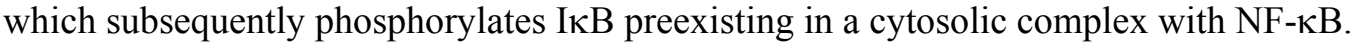

Phosphorylation-induced polyubiquitination targets IкB for proteasomal degradation consequently releasing NF- $\mathrm{KB}$ that then translocates to the nucleus where it binds to $\mathrm{\kappa B}$ sites and thus promotes transcription of inflammatory genes [168].

NF- $\kappa B$ binds DNA as homo- or heterodimer and five different NF- $\kappa B$ family members are known: RelA/p65, RelB, c-Rel, p100/p52 and p105/p50 that all share an N-terminal Rel homology domain (RHD). P65, RelB and c-Rel additionally contain a transactivation domain (TAD) which facilitates transcription whereas p50 and p52 homodimers act repressive as they lack this domain. The most common and best studied NF-kB dimer is p65/p50 [168].

Several ankyrin repeat domains are characteristic for the IкB family. The typical members

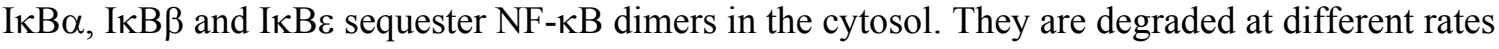
upon stimulation and also possess specific re-synthesis kinetics [169]. As NF- $\kappa B$ target genes, the

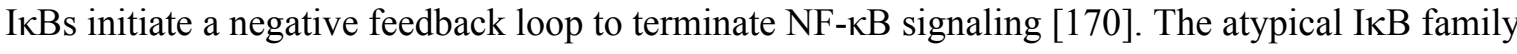

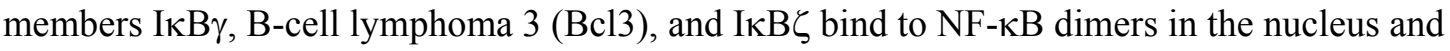
modulate their transcription activation potential at this level [168]. The precursor proteins p100 and p105 can also be classified as IкBs with ankyrin repeat domains despite constitutive processing to p52 and p50 even in the basal state. P100 and p105 may also dimerize with other NF- $\kappa B$ subunits e.g. RelB and c-Rel, respectively, retaining this complex in the cytosol in unstimulated cells. Stimulusdependent processing of p100 and p105 to p52 and p50 then yields active NF- $\mathrm{kB}$ dimers [168].

The canonical pathway described above involves the heterotrimeric IKK complex, IKK $\beta$ dependent phosphorylation of IKB $\alpha$ and subsequent release of p65/p50 [168, 171]. While IKK $\alpha$ is dispensable for canonical signaling, it is required for noncanonical NF- $\kappa B$ activation [172]. The noncanonical pathway is initiated by IKK $\alpha$ dimers that phosphorylate p100 upon stimulation. As p100 preexists in a complex with RelB, processing to p52 generates the RelB/p52 dimer, which is able to induce a subset of NF- $\kappa B$ target genes [173]. Noncanonical NF- $\kappa B$ activation has been described for example downstream of $\mathrm{CD} 40$, lymphotoxin $\beta$ receptor (LT $\beta \mathrm{R})$, and B-cell activating factor receptor (BAFFR) [174-176].

PTMs of NF-kB subunits also influence inflammatory signals and p65 has been studied extensively in this regard. Inducible phosphorylation, acetylation, ubiquitylation, prolyl isomerisation, poly(ADP-ribosyl)ation, monomethylation, and S-nitrosylation have been reported so far. Their presence affects the subcellular localization, the stability of DNA binding and the affinity to coactivator and corepressor complexes which determine the NF- $\kappa \mathrm{B}$ transcription activation potential [168].

Besides the NF- $\mathrm{KB}$ pathway, activator protein 1 (AP-1) signaling plays an important role in inflammatory reactions. The induction of MAPK cascades e.g. downstream of TNFR and TLRs leads to activation of AP-1, which similar to NF- $\mathrm{kB}$ is a homo- or heterodimeric transcription factor. The subunits belong to the Jun, Fos or activating transcription factor (ATF) families of basic-region leucine-zipper (B-ZIP) proteins that bind DNA at specific sequences and thus induce transcription of inflammatory target genes. A well-studied example is the activation of JNK, which in turn translocates to the nucleus where it phosphorylates c-jun thereby promoting AP-1's transcription activation potential [177, 178].

Finally, interferon regulatory factors (IRFs) mediate the induction of interferons and are as such critical in the response to viral infections [179].

The many players within the NF- $\mathrm{KB}$ and AP-1 pathway illustrate the complexity and redundancy of inflammatory signaling. This complexity is necessary to allow the body to mount a highly specific immune response to different kinds of injury and infection in order to protect the body at all times. The nature of inflammation is transient and therefore termination of immune responses is 
as important as initiation. If inflammatory reactions do not resolve and become chronic, they in fact turn detrimental and harmful to the body. Chronic inflammation also accompanies many pathologies including type 2 diabetes and cardiovascular diseases.

Inhibition of inflammation may occur at several levels. Changes in gene expression of the proinflammatory transcription factors themselves and/or their upstream regulators affect inflammatory

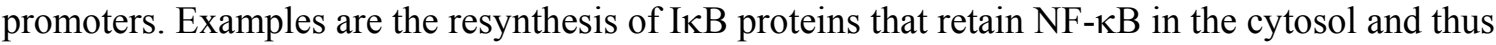
block transcription and the induction of repressive $\mathrm{p} 50$ or $\mathrm{p} 52$ homodimers that compete for $\mathrm{\kappa B}$ sites in the nucleus [168].

PTMs also interfere with inflammatory signaling. Suppressor of cytokine signaling 1 (SOCS1) for example is able to ubiquitinate p65 and its overexpression inhibits IL-1 $\beta$-dependent NF- $\kappa B$ activation [180]. Then, A20-deficient mice develop severe inflammation because the dual ubiquitin editing enzyme A20 targets important signaling molecules like RIP1 and TRAF6 for degradation, thereby confining inflammatory processes $[181,182]$. As phosphorylation events are important during the activation of most inflammatory pathways, changes in kinase and phosphatase activity influence pro-inflammatory gene expression. Again, the NF- $\kappa B$ pathway provides excellent examples: IKK $\beta$ deficient MEFs can neither phosphorylate IkB $\alpha$ nor p65 while IKK $\alpha$-deficient MEFs normally

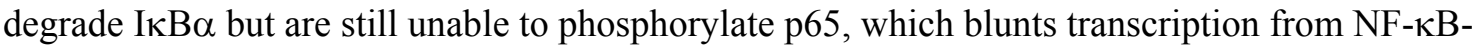
inducible promoters [183]. Inversely, mice lacking Wip1, the only known p65-specific serine phosphatase, display increased NF- $\mathrm{KB}$ target gene expression alongside higher p65 phosphorylation levels [184].

Transrepression by NRs has emerged as a potent mechanism to confine inflammation. Accordingly, PPAR $\alpha$ activation reduces expression of IL-6, cyclooxygenase 2 (COX2), vascular cell adhesion molecule 1(VCAM1) and other inflammatory factors in different cell types whereas PPAR $\alpha$ deletion renders mice hypersensitive to LPS [185-187]. PPAR $\gamma$ ligands and glucocorticoids, activators of the GR, likewise exhibit strong anti-inflammatory effects [188-191]. In contrast to transactivation that requires direct NR-DNA binding, transrepression may occur indirectly without direct contact to DNA.

Several molecular mechanisms of transrepression were established so far. DNA-binding

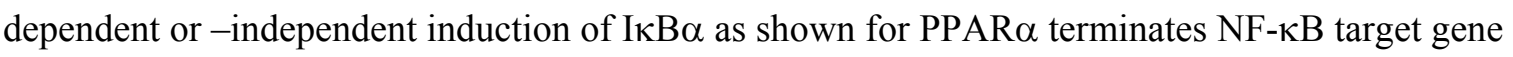
expression [192-194]. Moreover, competition for a limiting pool of coactivators like CBP results in mutual antagonism between inflammatory and NR pathways $[195,196]$. NRs may also disrupt the coactivator complex at inflammatory transcription factors by binding either to the transcription factor thus preventing coactivator binding (e.g. GR on p65) or to the coactivator thus hindering its recruitment [197]. Additional cofactors like nuclear TR-interacting protein 6 may favor GR binding, which in turn promotes transrepression, while secondary recruitment of corepressors like glutamate receptor-interacting protein or CoREST propagate this state [198-200]. PPAR $\gamma$ and LXR can further inhibit corepressor clearance from NF- $\mathrm{\kappa B}$ by preventing proteasomal degradation of NcoR 1 in a ligand- and SUMOylation dependent manner [201, 202]. SUMOylation is also implicated in LXRmediated transrepression of STAT1 downstream of interferon signaling [203]. Furthermore, PPAR $\alpha$ interacts with both c-jun and p65 to repress AP-1- and NF- $\mathrm{kB}$-driven gene expression, respectively [204]. As a consequence of this direct interaction, NR and inflammatory signaling pathways reciprocally interfere with each other constituting a negative cross-talk. Finally, GR may also constrain both transcription initiation and elongation by blocking RNA polymerase II hyperphosphorylation and chromatin remodeling by tethering HDACs to promoters of inflammatory genes [205-208].

\subsection{Obesity and inflammation}


Overweight and obesity do not only increase the risk for metabolic complications like insulin resistance but also foster a sterile, low-grade inflammation. This is evidenced by high plasma levels of circulating pro-inflammatory cytokines (IL-1, IL-6, IL-8, IL-12, and TNF $\alpha$ ), chemokines (monocyte chemoattractant protein (MCP) 1/CCL2, RANTES/CCL5, MIP-1), acute phase proteins (C-reactive protein, serum amyloid A, ferritin), adipokines associated with insulin resistance (retinol binding protein 4 and resistin), and procoagulative and hypertensive factors (plasminogen activator inhibitor 1 and angiotensinogen) in obese patients [209]. Inversely, negative acute phase proteins (transcortin and transferrin) and adipokines associated with insulin sensitivity (adiponectin, visfatin, omentin, and vaspin) are lowered in plasma of those subjects [209].

As expansion of adipose depots is the prime effect of obesity, an inflammatory reaction in WAT is the major source of elevated circulating pro-inflammatory factors [210]. WAT inflammation thereby involves both adipocytes and different immune cells that reside within WAT. Activation of the $\mathrm{NF}-\mathrm{\kappa B}$ and AP-1 pathways in adipocytes is a critical event in this process as it leads to expression and secretion of pro-inflammatory cytokines but also to adipocyte insulin resistance because IKK and JNK are able to phosphorylate IRS1 at inhibitory serine residues [211]. Consequently, JNK deletion ameliorates insulin resistance and improves insulin receptor signaling in obese animals [212].

To date, it is unknown which primary stimulus sets off the inflammatory reaction, but a number of aberrantly active cellular processes in WAT of obese subjects were shown to contribute. The presence of pro-inflammatory cytokines promotes IKK and JNK activation and indeed treatment of adipocytes with TNF $\alpha$ inhibits IRS1 action. In contrast, animals with disrupted TNF $\alpha$ signaling are protected from obesity-induced insulin resistance [211,213]. High levels of free fatty acids that prevail in obesity are able to induce pro-inflammatory TLR signaling and consequently, TLR4 deletion rescues animals from obesity-induced insulin-resistance [214]. Furthermore, ROS levels are aberrantly high in accumulated fat producing oxidative stress and, as a result, $\mathrm{NF}-\mathrm{\kappa B} / \mathrm{AP}-1$ signaling [215]. If the capacity of adipocytes to store fat is exceeded, ER stress arises and free fatty acids leak into the cytoplasm where they in turn activate JNK [216]. The expansion of adipocytes might also outbalance angiogenesis, which leads to tissue hypoxia and the induction of hypoxia-inducible factor $1 \alpha(\mathrm{HIF}-1 \alpha)$ that itself promotes pro-inflammatory cytokine expression [217]. In combination, ER stress and hypoxia exacerbate adipocyte necrosis. The dying cells then nucleate the formation of crown-like structures (areas of necrotic cells surrounded by macrophages), which are absent in lean animals [218].

Adipose tissue macrophages (ATMs) are plastic cells that may polarize towards an antiinflammatory M2 or a pro-inflammatory M1 state. The two phenotypes are characterized by the distinct sets of cytokines that they express. Hence, the highly inflammatory TNF $\alpha$, IL-1 $\beta$ and IL- 6 are secreted by M1 macrophages while M2 macrophages produce anti-inflammatory factors like IL-10. In WAT of lean animals, M2 macrophages are more prominent than M1 macrophages. Their polarization is driven by adipocyte-derived IL-13, IL-4 and adiponectin as well as the prevalence of unsaturated free fatty acids leading to PPAR activation [219-221]. Accordingly, myeloid ablation of PPAR $\gamma$ or PPAR $\beta / \delta$ impairs M2 skewing and fosters inflammation and insulin resistance $[219,222]$. M2 macrophages exhibit an oxidative metabolic profile and PGC-1 $\beta$ is essential in initiating M2 polarization [223].

In contrast, M1 macrophages are highly enriched in WAT of obese animals where they amplify and sustain tissue inflammation [224, 225]. The altered cytokine/adipokine profile in fat, high levels of saturated free fatty acids and the emergence of crown-like structures promote the phenotypic switch from M2 to M1 macrophages [226]. M1 macrophages also express MCP-1, which attracts monocytes that migrate from the circulation into WAT where they differentiate into M1 macrophages further perpetuating inflammation. Adipose tissue-specific overexpressing of MCP-1 thus renders 
animals insulin resistant, while deletion of the MCP-1 receptor CCR2 prevents M1 macrophage accumulation and maintains insulin sensitivity under high fat feeding [227-229]. Similarly, myeloid deletion of TLR4, JNK or IKK $\beta$ interferes with M1 macrophage polarization and consequently rescues insulin sensitivity on a high fat diet without differences in body weight gain [230-232].

Besides ATMs, other immune cells contribute to both the anti-inflammatory, insulin sensitive, and the pro-inflammatory, insulin resistant state, respectively. Eosinophils, CD4+ regulatory $\mathrm{T}$ and Th2 cells all reside in WAT of lean animals where they preserve M2 macrophage activation and insulin sensitivity while the T cell balance in obese animals tips towards Th1 cells that secret IFN $\gamma$, hence skewing macrophages towards the M1 phenotype [233-236]. This polarization is further advanced by pro-inflammatory neutrophils, CD8+ effector T cells, and B cells that all have been detected in WAT in the early stages of obesity [237-239]. Therefore, depletion of immune cells types associated with M1 polarization or induction of M2-sustaining immune cells ameliorates insulin resistance $[233,234,239,240]$.

In other organs, inflammatory reactions during the course of obesity have received less attention. The liver plays a major role in glucose metabolism due to hepatic gluconeogenesis. M1 polarization of Kuppfer cells (liver macrophages) is now thought to contribute to hepatic inflammation, insulin resistance and steatosis. Recently, pancreatic $\beta$ cell failure has also been linked to islet inflammation and M1 macrophage accumulation [241]. It therefore appears that inflammation with M1 macrophage polarization could be a general mechanism underlying organ dysfunction in obesity.

The situation in skeletal muscle is somewhat less clear. Intramuscular fat depots form in obese animals and attract inflammatory macrophages, however to a much smaller extent compared to bona fide adipose tissue [224]. These macrophages exert a negative influence on muscle insulin sensitivity as shown in obese animals with myeloid deletion of either JNK or IKK $\beta[231,232]$. In these models, inhibition of M1 macrophage activation preserved muscle insulin sensitivity [231, 232]. The same effect was observed after depletion of $\mathrm{Cd} 11 \mathrm{c}+$ cells that correspond to the main M1 macrophage subset in muscle [242]. Inversely, even lean animals with myeloid deletion of PPAR $\gamma$ developed muscle insulin resistance, which deteriorated in the obese state due to impaired M2 macrophage polarization [243]. In contrast, myeloid deletion of PPAR $\beta / \delta$ or TLR4 did not entail any effect on muscle insulin sensitivity [219, 230].

These observations imply that skeletal muscle insulin resistance is at least partially regulated by mechanisms that are different from WAT. Investigating these common and distinct processes in skeletal muscle warrants further studies. The caveat of myeloid deletion approaches is however that all macrophages in the body are polarized towards one or the other phenotype. Distinguishing between purely skeletal muscle-specific cross-talk of macrophages and myocytes versus whole body effects on the muscle e.g. through generally lower circulating cytokine levels remains a difficult endeavor. Future experiments will have to discern the exact role of M1 and M2 macrophages in skeletal muscle under conditions of obesity.

\subsection{Inflammatory pathways in skeletal muscle}

Adult skeletal muscle contains substantial amounts of different NF- $\kappa \mathrm{B}$ family members, their role in muscle physiology is however not fully resolved. It is unclear whether NF- $\mathrm{kB}$ is a promyogenic or an anti-myogenic factor during muscle differentiation as relevant data are conflicting, but suppression of myogenesis by means of inhibiting MyoD, myogenin and myofibrillar gene expression has been linked to canonical NF- $\kappa B$ signaling [244-252]. In contrast, noncanonical NF- $\kappa B$ signaling that involves IKK $\alpha$ and RelB does not affect myogenesis but drives an oxidative muscle fiber switch 
by targeting PGC-1 $\beta$, which stimulates mitochondrial biogenesis [253]. Exercise-dependent NF- $\mathrm{\kappa B}$ activation has also been reported in skeletal muscle and potentially induces ROS defense, regeneration of damaged fibers and adaptations in fuel metabolism [254-256].

In muscle pathology, inflammatory reactions accompany a number of disorders like cachexia, muscular dystrophy, atrophy, and inflammatory myopathies [257]. NF- $\mathrm{kB}$ activation in these contexts is a well-established disease mechanism that contributes significantly to deterioration of muscle function. This also is evident in mice with skeletal muscle-specific overexpression of IKK $\beta$, which causes severe muscle wasting while muscle-specific deletion of this kinase improves strength and counteracts denervation-induced atrophy and fiber type changes [258, 259]. Moreover, the latter model, similar to a p65 deletion model, regenerates faster from injury as inflammation is substantially inhibited in both mouse lines [252, 259].

Regeneration of skeletal muscle requires the activation of satellite cells (muscle stem cells), their fusion to damaged fibers or the formation of new fibers depending on the degree of injury. Satellite cell proliferation is stimulated by IL-6 while IL-4 promotes myoblast fusion [260, 261]. Satellite cells also attract and interact with monocytes/macrophages to foster muscle growth [262]. Therefore, macrophages are also engaged in the different stages of regeneration: M1 macrophages (CD68+/CD163-) readily remove cellular debris by phagocytosis directly after injury and contribute to satellite cell activation while M2 macrophages (CD68-/CD163+) invade the tissue later [263]. They promote satellite cell differentiation and muscle growth in later regenerative stages to restore muscle function [264]. The M1/M2 macrophage switch is presumably initiated by muscle-derived IL-4 [261]. In dystrophic muscle, M1 macrophage activation and concomitant M2 macrophage repression e.g. by IFN $\gamma$ exacerbates muscle wasting in DMD while conversely, symptoms are alleviated by IL-10, which activates M2 and represses M1 macrophages [265, 266].

\section{$4 \quad$ PGC-1 coactivators and inflammation in skeletal muscle}

\subsection{Anti-inflammatory effect of exercise}

Skeletal muscle has been recognized as an endocrine organ that releases myokines (musclederived cytokines) like IL-6, IL-8, and IL-15 during contraction [267]. These myokines presumably mediate beneficial effects of exercise both on the muscle itself and on distant organs. IL-6 has received most of the attention and the majority of studies deal with this myokine. The induction of IL-6 after exercise was speculated to be under the control of nuclear factor of activated T cells (NFAT) and/or p38/MAPK as opposed to NF- $\kappa$ B during inflammatory reactions [268]. While elevated IL-6 levels are also associated with chronic inflammation, the contraction-induced rise of IL-6 is transient and thus not detrimental. Accordingly, IL-6 infusion increases insulin-stimulated glucose disposal in humans whereas deletion of IL-6 in mice results in mature-onset diabetes [269, 270]. Importantly, IL-6 receptor expression is augmented concomitantly to IL-6 post exercise. This heightens "IL-6 sensitivity" while reciprocally, under conditions of chronic inflammation "IL-6 sensitivity" might be lost (analogous to insulin resistance with high levels of insulin) [271].

Diseases that are associated with a systemic, low-grade inflammation may be antagonized by physical activity e.g. diabetes, sarcopenia, and neurodegeneration [272-275]. Muscle-derived IL-6 preludes expression of the anti-inflammatory cytokines IL-1Ra and IL-10 in blood while inhibiting pro-inflammatory TNF $\alpha$ production [276, 277]. This skews the immune reaction towards a type 2 response.

Following contraction, plasma levels of immunomodulatory hormones like epinephrine, cortisol, growth hormone and prolactin are all high and suppress inflammatory reactions [272]. On 
monocytes, exercises reduce TLR1, TLR2, and TLR4 expression and function, alongside a decrease in major histocompatibility complex II and costimulatory molecules rendering these cells less inflammatory [278]. Potentiation of these effects after very strenuous training leads to temporary immunodepression as observed in high-performance athletes [272].

\subsection{Mutual influence of inflammatory factors and PGC-1s}

Inflammatory stimuli affect endogenous PGC-1 coactivator levels in different organs whereby LPS-induced sepsis is the most extensively studied model in this regard. In heart, kidney, and liver, PGC-1 $\alpha$, ERR $\alpha$ and MCAD mRNA was markedly reduced 16h after LPS injection [279]. Furthermore, in cardiac tissue, inflammation-dependent PGC- $1 \alpha$ repression was further confirmed in vitro and in vivo, which could be rescued by inhibiting the NF-кB pathway [280-282]. Sepsisassociated acute kidney injury is associated with swollen, dysfunctional mitochondria and reduced PGC-1 $\alpha$ levels that correlate with renal impairment [283]. This phenotype can be recapitulated by treatment of tubular cells with TNF $\alpha$ and reversed by excess PGC-1 $\alpha$ while lack of this coactivator results in persistent kidney injury after endotoxemia [283]. In contrast, one study reported an opposite regulation of PGC- $1 \alpha$ and PGC- $1 \beta$ in liver of septic mice, as both coactivators were induced in a TLR2-dependent manner [284].

In skeletal muscle, the regulation of $\mathrm{PGC}-1$ coactivators by inflammatory stimuli is ambiguous. An early study found that LPS, TNF $\alpha$, and IL- $1 \beta$ augment PGC- $1 \alpha$ expression resulting in increased oxidative phosphorylation while more recently, sepsis was shown to lower PGC-1 $\alpha$ and PGC-1 $\beta$ in skeletal muscle of rats $[61,285]$. In support of these data, PGC- $1 \alpha$ and PGC-1 $\beta$ are also reduced in diaphragm after LPS administration with concomitant decrease in fatty acid oxidation [286]. A more careful examination of the time-course revealed that intraperitoneal injection of LPS induced PGC- $1 \alpha$ in skeletal muscle after $2 \mathrm{~h}$, but decreased its expression after $24 \mathrm{~h}$, suggesting a shortterm up- but a long-term down-regulation [287]. This model is also well in line with the induction of PGC-1 $\alpha$ after exercise in the transient presence of myokines that return to basal levels quickly as opposed to the chronic, low-grade inflammation observed in metabolic disorders with dampened PGC1 coactivator levels in skeletal muscle. A repression of PGC- $1 \alpha$ and PGC- $1 \beta$ upon chronic TNF $\alpha$ or IL-1 $\beta$ exposure was also observed in $\mathrm{C} 2 \mathrm{C} 12$ myotubes [288]. Importantly, inflammatory stimulation with the activation of classical NF- $\kappa B$ signaling clearly impaired the oxidative phenotype in this system [288]. Cell culture studies with palmitate further back the abovementioned, dual regulation as long-term treatment repressed, while short-term treatment increased PGC-1 $\alpha$ expression [289]. However, one study also associated long-term palmitate administration with an increase in PGC-1 $\alpha$ in vascular smooth muscle cells [290].

A pathological condition frequently associated with muscle wasting and low oxidative capacity is chronic obstructive pulmonary disease (COPD). COPD patients also exhibit high TNF $\alpha$ levels in skeletal muscle alongside decreased PGC-1 $\alpha$ expression [291]. This repression can be replicated in vitro by chronically treating the $\mathrm{C} 2 \mathrm{C} 12$ muscle cell line with $\mathrm{TNF} \alpha$. The subsequent inhibition of oxidative phosphorylation is dependent on NF-אB [291, 292]. Similarly, TNF $\alpha$ is augmented in mice exposed to cigarette smoke while PGC- $1 \alpha$ levels in skeletal muscle of these animals are diminished [292]. The impairment in expression of PGC-1 $\alpha$ and some of its target genes is more pronounced in oxidative muscles [292]. Of note, plasma TNF $\alpha$ levels in COPD patients negatively correlate with PPAR $\alpha$ expression in skeletal muscle [293]. Overall, these data imply that chronic inflammatory stimulation and especially NF- $\kappa \mathrm{B}$ signaling lead to a suppression of PGC-1 coactivator levels. 
An inverse, body mass index-independent correlation between PGC-1 $\alpha$ and IL- 6 as well as $\mathrm{TNF} \alpha$ expression is also present in skeletal muscle of diabetic patients [151]. In accordance, mouse models that lack PGC-1 $\alpha$ in skeletal muscle or only express it heterozygously display higher IL-6 levels in muscle and blood [151]. Complete lack of muscle PGC-1 $\alpha$ further promotes the expression of pro-inflammatory markers like TNF $\alpha$ and CD68 in skeletal muscle [151]. After exercise that increases PGC- $1 \alpha$ levels in wild-type mice, excessive TNF $\alpha$ expression in muscle and blood can be observed in this model [105]. Therefore, low PGC-1 $\alpha$ levels in skeletal muscle are associated with inflammatory processes in muscle and the appearance of circulating pro-inflammatory cytokines.

A causal relationship between PGC-1 coactivators and inflammation has recently been established. PGC- $1 \alpha$ and PGC-1 $\beta$ were shown to diminish the increase in pro-inflammatory cytokine expression elicited by TNF $\alpha$, TLR agonists and saturated free fatty acids in C2C12 muscle cells [294]. In human aortic smooth muscle and endothelial cells PGC-1 $\alpha$ likewise decreased TNF $\alpha$-induced VCAM-1 and MCP-1 expression [295]. Mechanistically, the PGC-1 coactivators target the NF- $\kappa \mathrm{B}$ pathway and for example dampen expression of luciferase from an NF- $\mathrm{BB}$-drive reporter in vitro and in vivo $[142,294]$. More precisely, the PGC-1s lower phosphorylation of $\mathrm{p} 65$ in C2C12 cells and muscle-specific PGC-1 $\alpha$ transgenic mice [100, 294]. One study however found elevated p65 phosphorylation levels in this model and no difference between wild-type and transgenic mice concerning muscle IL-6 and TNF $\alpha$ expression after short-term, intraperitoneal LPS injection [296]. In vitro, transrepression by PPAR $\alpha$ is a second mechanism that contributes to the repression of proinflammatory cytokines in skeletal muscle cells [294].

Together, these results suggest that PGC-1 coactivators and inflammatory processes in skeletal muscle are linked in a reciprocal manner (Fig. 2). Therefore, high PGC-1 expression not only determines an oxidative metabolic state, but also favors an anti-inflammatory environment (Fig. 2A). Inversely, pro-inflammatory cytokines suppress PGC-1 coactivators leading to a more glycolytic metabolism in a highly inflammatory environment (Fig. 2B). The NF- $\kappa$ B pathways appears to be a nodal point in this mutual repressive action as NF- $\mathrm{\kappa B}$ signaling strongly induces pro-inflammatory genes and at the same time suppresses PGC-1 coactivator expression. Conversely, at least canonical $\mathrm{NF}-\kappa \mathrm{B}$ signaling can be restrained by PGC-1 coactivators constituting an interdependent, negative, molecular regulation of oxidative metabolism and inflammation in muscle cells (Fig. 2).

In macrophages, this antagonism has previously been described during alternative activation which is associated with a decrease in the expression of pro-inflammatory markers and requires PGC$1 \beta$ induction [223]. These M2 macrophages show signs of an oxidative metabolic program as opposed to $\mathrm{M} 1$ macrophages that rely mainly on glycolysis as energy producing pathway. PGC- $1 \beta$ expression in macrophages furthermore drives the generation of mitochondrial ROS, which are vital in pathogen clearance [297]. The role of PGC-1 $\alpha$ in macrophages is not well understood but it likely participates in M2-like polarization as hypothesized for macrophages in epidydimal adipose tissue while it is downregulated after LPS exposure which leads to M1 macrophage polarization [298, 299]. PGC-1 $\alpha$ inhibition in this case enables ROS production as many ROS detoxifying enzymes are among PGC-1 $\alpha$ target genes [299].

M1 and M2 macrophage-polarizing signals are mutually exclusive and thus preclude the opposite activation state. The anti-inflammatory cytokines IL-4, IL-10, and Il-13, for example, suppress M1 macrophage activation because they disturb NF- $\mathrm{\kappa B}$ signaling and STAT1 activation by inducing inhibitory p50 dimers and STAT3/STAT6 [300, 301]. STAT6 is an important molecular determinant of M2 macrophage activation that cooperates with Krüppel-like factor 4 (KLF4) to induce anti-inflammatory M2 and inhibit pro-inflammatory M1 genes [302]. Similarly, KLF2 also impairs $\mathrm{NF}-\kappa \mathrm{B}$ activation [303]. PPAR $\gamma$ and PPAR $\beta / \delta$ are required for M2 macrophage polarization. They induce both a more oxidative metabolic program within these immune cells and simultaneously 
transrepress pro-inflammatory promoters, which renders these nuclear receptors central players in the dichotomy between M1 and M2 macrophages reflecting the antagonism between oxidative metabolism and inflammatory gene expression [219, 222, 304]. If this adverse regulation that we propose to take place in macrophages and muscle cells also plays a role in other tissues remains to be determined. For example, canonical NF- $\mathrm{KB}$ signaling has previously been associated with positive regulation of mitochondrial biogenesis in embryonic fibroblasts and cancer cells [305, 306].

Transcription factors implicated in mitochondrial biogenesis are also potent inducers of the anti-inflammatory cytokines IL-10 and IL-1Ra in both macrophages and but also liver cells reinforcing opposite roles for oxidative metabolism and inflammation respectively [307]. IL-1Ra and IL-15 $\alpha$ induction in primary hepatocytes after fasting, exercise, glucagon, or cAMP exposure which coincides with PGC-1 $\alpha$ expression in these cells further confirms the association [308]. Elevation of IL-1Ra and IL-15 $\alpha$ is thereby dependent on PPAR $\alpha$ [308]. PPAR $\alpha$ thus seems to play a dual role in mediating the anti-inflammatory effect of oxidative metabolism: while this nuclear receptor acts transrepressive on the induction of NF-kB-dependent, pro-inflammatory genes, it also promotes the expression of antiinflammatory cytokines, at least in hepatocytes. Both activities in concert then shift the balance between pro- and anti-inflammatory gene expression. Similarly, conjugated linoleic acid ameliorates colitis in a model of inflammatory bowel disease by targeting PPAR $\gamma$ [309]. The treated mice show higher PGC-1 $\alpha$ levels while NF- $\kappa B$ activation and TNF $\alpha$ expression are decreased [309].

A direct negative effect of any of the PGC-1 coactivators on pro-inflammatory gene expression is somewhat unlikely, as they have been described unequivocally as transcription coactivators that recruit factors which facilitate transcription at the promoter. In contrast, no corepressor activity for the PGC-1s is known so far. Besides PPAR $\alpha$-dependent transactivation and transrepression, direct interaction of PGC- $1 \alpha$ or PGC- $1 \beta$ with NF- $\kappa \mathrm{B}$ family members has been reported in various cell types. In bone marrow stromal cells, constitutive binding of PGC-1 $\alpha$ to p65 and p50 was decreased in the presence of PPAR $\gamma$ ligands leading to the hypothesis that PGC-1 $\alpha$ is a shared coactivator that NF- $\kappa B$ and PPAR $\gamma$ compete for [310]. In hepatocytes, free fatty acids induce a p50-PGC-1 $\alpha$ interaction and binding of this complex to the IL-10 promoter however with uncertain results concerning the role of PGC-1 $\alpha$ in regard to coactivator or corepressor activity at this site [311]. In cardiomyocytes, binding of PGC- $1 \alpha$ to 655 that increased upon TNF $\alpha$ exposure was detected [312]. The authors propose that p65 inhibits PGC-1 $\alpha$ activity leading to a drop in PDK4 and subsequently higher glucose oxidation rates [312]. This would fit the model of NF-kB-dependent blockade of oxidative metabolism; some ambiguities concerning the exact mechanism however remain to be uncovered. In skeletal muscle cells, no direct interaction of p 65 or any other NF- $\kappa B$ family member and PGC- $1 \alpha$ or PGC-1 $\beta$ has been found.

PGC- $1 \alpha$ may also interfere with upstream NF- $\kappa \mathrm{B}$ signaling. An induction of $\mathrm{I} \kappa \mathrm{B} \alpha$ has been observed in quadriceps of whole body PGC-1 $\alpha$ transgenic mice in vivo but not in vitro while Bcl3 interacts with PGC- $1 \alpha$ synergistically to coactivate ERR $\alpha$ and PPAR $\alpha$ in cardiomyocytes $[313,314]$. The reciprocity of oxidative metabolism and inflammatory signaling may thus extend beyond the antithetic roles of PGC-1 and NF- $\mathrm{KB}$ at the transcription activation level and could involve mechanisms like cofactor competition and upregulation of phosphatases. The molecular details of such processes however remain to be investigated in future studies.

Functionally, it is clear that inflammation in WAT substantially contributes to the development of insulin resistance under conditions of overfeeding with detrimental crosstalk between immune and fat cells (see above). Cues that this mechanism might also be in place in skeletal muscle derive from myeloid deletion studies where silencing of the pro-inflammatory genes JNK1, or IKK $\beta$, in the hematopoietic compartment or depletion of $\mathrm{Cd} 11 \mathrm{c}^{+}$cells increased insulin-stimulated glucose disposal (which correlates to muscle insulin sensitivity) under high fat diet feeding conditions whereas 
hematopoietic PPAR $\gamma$ deletion had the opposite effect [231, 232, 242, 243]. M1 macrophage polarization thus seems to be associated with muscle insulin resistance while M2 polarization is linked to muscle insulin sensitivity. Accordingly, an accumulation of M1 macrophages in obese rodents and humans has been described and pro-inflammatory macrophage markers within skeletal muscle correlate with poor glycemic control in diabetic patients whereas anti-inflammatory markers correlate with improved parameters in this setting $[315,316]$. . The model proposed here therefore implies that in the insulin sensitive state, M2 macrophages are the predominant phenotype in skeletal muscle (Fig. $3)$. Endurance training, which increases PGC-1 $\alpha$ in the muscle cells, leads to the release of myokines that further mediate the anti-inflammatory effects of exercise e.g. downregulation of certain TLRs on monocytes. In the ensuing anti-inflammatory environment, macrophages would remain polarized in an alternative activation state and retroact on myocytes through the release of anti-inflammatory factors that favor the maintenance of insulin sensitivity (Fig. 3). Indeed, a single bout of exercise has recently been shown to increase insulin sensitivity in murine skeletal muscle and entail a concomitant accumulation of M2 macrophages [317]. If the balance between muscle cells and M2 macrophages is lost, e.g. in the etiology of diabetes, a vicious cycle would commence ultimately resulting in insulin resistance in an inflamed environment. This involves a switch to M1 macrophages, the secretion of pro-inflammatory cytokines by both classically activated macrophages and muscle cells worsening insulin sensitivity on one hand and promoting inflammation on the other hand concomitant with a decrease in muscle oxidative capacity and PGC-1 coactivator levels (Fig. 3). The antagonism between oxidative metabolism and inflammatory signaling would thus not only provide an attractive explanation for the different states of muscle cells in healthy and obese subjects but is further extended to the macrophage phenotypes. High PGC- $1 \alpha$ levels in skeletal muscle and high PGC- $1 \beta$ levels in M2 macrophages would hereby correspond to the trained state while downregulation of PGC-1 coactivators in both skeletal muscle and macrophages would translate into an insulin resistant, proinflammatory environment in inactive, obese patients (Fig. 3). Detailed evidence for such a myocytemacrophage crosstalk remains to be provided.

In muscle diseases, such a model would also be feasible because ectopic expression of PGC$1 \alpha$ ameliorated fiber integrity and function, for example in DMD, sarcopenia, a mitochondrial myopathy and denervation-induced fiber atrophy $[100,101,140,143]$. Reducing the inflammatory reaction in these conditions likely explains at least a part of the beneficial PGC-1 $\alpha$ effect as other strategies to counteract inflammation have proven useful e.g. in DMD [101, 265, 266]. Conversely, endurance training that fosters PGC-1 $\alpha$ expression protects against fiber damage, muscle inflammation and soreness.

Taken together, muscle cells take active part in immune reactions and are thus able to influence immune cells e.g. in their activation state. The complex interplay between those cell types is only incompletely understood to date and further studies are needed to elucidate the molecular mechanisms underlying this crosstalk. The antagonism between PGC-1 coactivators and inflammatory processes should thereby receive special attention as an imbalance is associated with metabolic and musculoskeletal diseases.

\section{Conclusion}

Metabolism and inflammation used to be considered as two completely independent processes in the body. In the past decade, it has become clear that both are tightly linked at multiple levels, which is particularly evident in cases where homeostasis is lost like nutritional overload. The dysregulation of metabolism is associated with an inflammatory reaction in different organs that significantly contributes to the development of insulin resistance while in the opposite, healthy state, 
an anti-inflammatory environment prevails. We have focused here on this interaction in skeletal muscle, which is both metabolically and immunologically active. One of the nodal points in this context seems the crosstalk of oxidative metabolism through the PGC-1 coactivators and NF- $\mathrm{kB}$ signaling that mutually suppress each other. It will be of prime interest to define this relationship in greater detail in the future and take pathological muscle conditions into account. This would pave the way for treatment strategies aimed not only at bringing back metabolic balance but also at halting inflammation to improve muscle structure and function.

Although no specific activators of PGC- $1 \alpha$ or PGC- $1 \beta$ are available at the moment, exercise induces PGC-1 $\alpha$ in skeletal muscle and training has been shown to counteract diseases with sterile inflammation like diabetes and neurodegeneration. Exercise capacity is furthermore a strong predictor of all-cause mortality while a sedentary lifestyle is a major risk factor for chronic diseases. Developing training regimes that optimally target an induction of oxidative metabolism and concomitantly block inflammation is a promising route to take as this would improve both the metabolic and the immune dysfunction very likely without major side effects.

\section{Figure legends}

Figure 1 Schematic representation of the murine PGC-1 family members and transcript variants. AD, activation domain; ID, inhibitory domain; RS, arginine-/serine-rich domain; RRM, RNA recognition and splicing motif; S, serine-rich domain; P, proline-rich domain; L, LXXLL or LLXXL motif; Q, glutamine-rich domain 1 and 2. Numbers indicate amino acid positions and refer to RefSeq transcripts; different $\mathrm{N}$-terminal amino acid sequences corresponding to a different exon 1 and arise from alternative promoter usage are indicated; an asterisk indicates additional $\mathrm{C}$-terminal amino acids that are not shared by all splice variants $[27,29,35,44-48,318]$.

Figure 2 Molecular mechanisms of the mutual antagonism between oxidative metabolism and inflammation in skeletal muscle. A PGC-1 coactivators negatively regulate inflammation. PGC-1 coactivators are at the crossroad of cellular respiration and inflammation as PGC- $1 \alpha$ and PGC-1 $\beta$ coactivate a set of nuclear receptors and transcription factors to induce genes involved in oxidative metabolism. At the same time PGC-1 coactivators interfere with inflammatory signaling at different levels. PGC- $1 \alpha$ and PGC- $1 \beta$ inhibit phosphorylation of the NF- $\kappa B$ subunit $\mathrm{p} 65$ and thus restrain NF$\kappa \mathrm{B}$ signaling resulting in diminished expression of pro-inflammatory cytokines. Both coactivators also induce PPAR $\alpha$. This nuclear receptor acts transrepressive on the promoters of pro-inflammatory genes equally limiting their expression. Inversely, expression of some anti-inflammatory genes has been shown to depend on PPAR $\alpha$. Whether PGC- $1 \alpha$ and/or PGC-1 $\beta$ play a direct role in coactivating PPAR $\alpha$ on the promoters of those genes is not known. Taken together, PGC-1 coactivators lower proinflammatory but induce anti-inflammatory genes contributing to a less inflamed environment. $\mathbf{B}$ Classical NF- $\kappa B$ signaling inhibits PGC-1 expression. Inflammatory stimuli like NF- $\kappa \mathrm{B}$ activation reduce expression levels of both PGC- $1 \alpha$ and PGC-1 $\beta$ in various contexts. Expression of PGC- $1 \alpha$ is driven by CREB and MEF2, the latter being coactivated by PGC-1 $\alpha$ in a positive autoregulatory loop. NF- $\kappa B$ might constrain binding of those transcription factors to the PGC-1 $\alpha$ promoter, the exact mechanism of this inhibition is however not known. Decreased PGC-1 coactivator expression in turn results in a decline of oxidative metabolism. PGC-1, peroxisome proliferator-activated receptor $\gamma$ coactivator 1; PPAR $\alpha$, peroxisome proliferator-activated receptor $\alpha$; PPRE, PPAR response element; 
MEF2, myocyte enhancer factor 2; CREB, cAMP response element binding protein; CRE, cAMP response element

Figure 3 Potential crosstalk of skeletal muscle and the immune system. In the trained state, skeletal muscle is insulin sensitive and PGC-1 $\alpha$ levels are chronically increased. Muscle contraction leads to the release of myokines, which mediate many of the beneficial effect of exercise both locally and systemically. Analogous to the events in fat tissue of lean animals and humans, exposure of muscleresident macrophages to these myokines could polarize them towards an anti-inflammatory M2 phenotype. These M2 macrophages in turn further secrete anti-inflammatory factors that help to maintain skeletal muscle in an insulin sensitive state. On the other side of the spectrum, PGC-1 $\alpha$ and PGC-1 $\beta$ are chronically lowered in skeletal muscle of inactive/obese/diabetic animals or patients. The release of pro-inflammatory factors from this insulin resistant muscle tissue presumably drives polarization of muscle-resident macrophages towards a pro-inflammatory M1 phenotype. M1 macrophages themselves release more pro-inflammatory cytokines, which negatively act back onto the muscle contributing to deterioration of muscle contractile and metabolic function. In macrophages, PGC- $1 \beta$ has been shown to be required for M2 macrophage activation and PGC- $1 \alpha$ seems to be involved in this process at least in some contexts while production of reactive oxygen species typical for M1 macrophage activation is only possible in the absence of PGC-1 $\alpha$. A comprehensive understanding of the regulation of both coactivators in different macrophage activation states is however still missing. PGC-1, peroxisome proliferator-activated receptor $\gamma$ coactivator 1 ; M1, classically activated, pro-inflammatory macrophage; M2, alternatively activated, anti-inflammatory or regulatory macrophage

\section{Acknowledgements}

This review is dedicated to the memory of Dr. Martine Christe. Research in our laboratory is supported by the Swiss National Science Foundation, the Muscular Dystrophy Association USA (MDA), the SwissLife 'Jubiläumsstiftung für Volksgesundheit und medizinische Forschung', the Swiss Society for Research on Muscle Diseases (SSEM), the Swiss Diabetes Association, the Roche Research Foundation, the United Mitochondrial Disease Foundation (UMDF), the Association Française contre les Myopathies (AFM), the Gebert-Rüf Foundation "Rare Diseases" Program, the University of Basel and the Biozentrum.

\section{Conflict of interest statement}

The authors declare that they have no conflict of interest.

\section{References}

1. Thews G, Mutschler E, Vaupel P. (1999) Skelett, Muskulatur und Bindegewebe. In: Anatomie, Physiologie, Pathophysiologie des Menschen, 5th edn. Wissenschaftliche Verlagsgesellschaft $\mathrm{mbH}$, Stuttgart, pp. 553-603

2. Lodish H, Berk A, Kaiser CA, Krieger M, Scott MP, Bretscher A, Ploegh H, Matsudaira P. (2007) Cellular energetics. In: Molecular Cell Biology, 6th edn. W.H. Freeman and Company, New York, pp. 479-532

3. Samuel VT, Shulman GI (2012) Mechanisms for insulin resistance: common threads and missing links. Cell 148: 852-71 
4. Evans JL, Goldfine ID, Maddux BA, Grodsky GM (2002) Oxidative stress and stress-activated signaling pathways: a unifying hypothesis of type 2 diabetes. Endocrine reviews 23: 599-622

5. Xu C, Bailly-Maitre B, Reed JC (2005) Endoplasmic reticulum stress: cell life and death decisions. J Clin Invest 115: 2656-64

6. Hage Hassan R, Hainault I, Vilquin JT, Samama C, Lasnier F, Ferre P, Foufelle F, Hajduch E (2012) Endoplasmic reticulum stress does not mediate palmitate-induced insulin resistance in mouse and human muscle cells. Diabetologia 55: 204-14

7. Rieusset J, Chauvin MA, Durand A, Bravard A, Laugerette F, Michalski MC, Vidal H (2012) Reduction of endoplasmic reticulum stress using chemical chaperones or Grp78 overexpression does not protect muscle cells from palmitate-induced insulin resistance. Biochem Biophys Res Commun 417: 439-45

8. Puigserver P, Wu Z, Park CW, Graves R, Wright M, Spiegelman BM (1998) A cold-inducible coactivator of nuclear receptors linked to adaptive thermogenesis. Cell 92: 829-39

9. Vega RB, Huss JM, Kelly DP (2000) The coactivator PGC-1 cooperates with peroxisome proliferator-activated receptor alpha in transcriptional control of nuclear genes encoding mitochondrial fatty acid oxidation enzymes. Mol Cell Biol 20: 1868-76

10. Wang YX, Lee CH, Tiep S, Yu RT, Ham J, Kang H, Evans RM (2003) Peroxisome-proliferatoractivated receptor delta activates fat metabolism to prevent obesity. Cell 113: 159-70

11. Oberkofler H, Schraml E, Krempler F, Patsch W (2003) Potentiation of liver X receptor transcriptional activity by peroxisome-proliferator-activated receptor gamma co-activator 1 alpha. Biochem J 371: 89-96

12. Zhang Y, Castellani LW, Sinal CJ, Gonzalez FJ, Edwards PA (2004) Peroxisome proliferatoractivated receptor-gamma coactivator 1alpha (PGC-1alpha) regulates triglyceride metabolism by activation of the nuclear receptor FXR. Genes Dev 18: 157-69

13. Savkur RS, Bramlett KS, Stayrook KR, Nagpal S, Burris TP (2005) Coactivation of the human vitamin $\mathrm{D}$ receptor by the peroxisome proliferator-activated receptor gamma coactivator-1 alpha. Mol Pharmacol 68: 511-7

14. Shiraki T, Sakai N, Kanaya E, Jingami H (2003) Activation of orphan nuclear constitutive androstane receptor requires subnuclear targeting by peroxisome proliferator-activated receptor gamma coactivator-1 alpha. A possible link between xenobiotic response and nutritional state. J Biol Chem 278: 11344-50

15. Bhalla S, Ozalp C, Fang S, Xiang L, Kemper JK (2004) Ligand-activated pregnane X receptor interferes with HNF-4 signaling by targeting a common coactivator PGC-1alpha. Functional implications in hepatic cholesterol and glucose metabolism. J Biol Chem 279: 45139-47

16. Tcherepanova I, Puigserver P, Norris JD, Spiegelman BM, McDonnell DP (2000) Modulation of estrogen receptor-alpha transcriptional activity by the coactivator PGC-1. J Biol Chem 275: 16302-8

17. Huss JM, Kopp RP, Kelly DP (2002) Peroxisome proliferator-activated receptor coactivator1alpha (PGC-1alpha) coactivates the cardiac-enriched nuclear receptors estrogen-related receptor-alpha and -gamma. Identification of novel leucine-rich interaction motif within PGC1alpha. J Biol Chem 277: 40265-74

18. Yoon JC, Puigserver P, Chen G, Donovan J, Wu Z, Rhee J, Adelmant G, Stafford J, Kahn CR, Granner DK, Newgard CB, Spiegelman BM (2001) Control of hepatic gluconeogenesis through the transcriptional coactivator PGC-1. Nature 413: 131-8

19. Rhee J, Inoue Y, Yoon JC, Puigserver P, Fan M, Gonzalez FJ, Spiegelman BM (2003) Regulation of hepatic fasting response by PPARgamma coactivator-1alpha (PGC-1): Requirement for hepatocyte nuclear factor 4alpha in gluconeogenesis. Proc Natl Acad Sci U S A 100: 4012-7

20. Delerive P, Wu Y, Burris TP, Chin WW, Suen CS (2002) PGC-1 functions as a transcriptional coactivator for the retinoid $X$ receptors. J Biol Chem 277: 3913-7

21. Knutti D, Kaul A, Kralli A (2000) A tissue-specific coactivator of steroid receptors, identified in a functional genetic screen. Mol Cell Biol 20: 2411-22 
22. Puigserver P, Rhee J, Donovan J, Walkey CJ, Yoon JC, Oriente F, Kitamura Y, Altomonte J, Dong H, Accili D, Spiegelman BM (2003) Insulin-regulated hepatic gluconeogenesis through FOXO1-PGC-1alpha interaction. Nature 423: 550-5

23. Olmos Y, Valle I, Borniquel S, Tierrez A, Soria E, Lamas S, Monsalve M (2009) Mutual dependence of Foxo3a and PGC-1alpha in the induction of oxidative stress genes. J Biol Chem 284: $14476-84$

24. Wu Z, Puigserver P, Andersson U, Zhang C, Adelmant G, Mootha V, Troy A, Cinti S, Lowell B, Scarpulla RC, Spiegelman BM (1999) Mechanisms controlling mitochondrial biogenesis and respiration through the thermogenic coactivator PGC-1. Cell 98: 115-24

25. Moore ML, Park EA, McMillin JB (2003) Upstream stimulatory factor represses the induction of carnitine palmitoyltransferase-lbeta expression by PGC-1. The Journal of biological chemistry 278: 17263-8

26. Michael LF, Wu Z, Cheatham RB, Puigserver P, Adelmant G, Lehman JJ, Kelly DP, Spiegelman BM (2001) Restoration of insulin-sensitive glucose transporter (GLUT4) gene expression in muscle cells by the transcriptional coactivator PGC-1. Proc Natl Acad Sci U S A 98: 3820-5

27. Lin J, Puigserver P, Donovan J, Tarr P, Spiegelman BM (2002) Peroxisome proliferatoractivated receptor gamma coactivator 1 beta (PGC-1beta), a novel PGC-1-related transcription coactivator associated with host cell factor. J Biol Chem 277: 1645-8

28. Kressler D, Schreiber SN, Knutti D, Kralli A (2002) The PGC-1-related protein PERC is a selective coactivator of estrogen receptor alpha. J Biol Chem 277: 13918-25

29. Kamei Y, Ohizumi H, Fujitani Y, Nemoto T, Tanaka T, Takahashi N, Kawada T, Miyoshi M, Ezaki O, Kakizuka A (2003) PPAR\{gamma\} coactivator 1 \{beta\}/ERR ligand 1 is an ERR protein ligand, whose expression induces a high-energy expenditure and antagonizes obesity. Proc Natl Acad Sci U S A 100: 12378-83

30. Hentschke M, Susens U, Borgmeyer U (2002) PGC-1 and PERC, coactivators of the estrogen receptor-related receptor gamma. Biochem Biophys Res Commun 299: 872-9

31. Lin J, Yang R, Tarr PT, Wu PH, Handschin C, Li S, Yang W, Pei L, Uldry M, Tontonoz P, Newgard $C B$, Spiegelman BM (2005) Hyperlipidemic effects of dietary saturated fats mediated through PGC-1beta coactivation of SREBP. Cell 120: 261-73

32. Oberkofler H, Hafner M, Felder T, Krempler F, Patsch W (2009) Transcriptional co-activator peroxisome proliferator-activated receptor (PPAR)gamma co-activator-1beta is involved in the regulation of glucose-stimulated insulin secretion in INS-1E cells. J Mol Med 87: 299-306

33. Wolfrum C, Stoffel M (2006) Coactivation of Foxa2 through Pgc-1beta promotes liver fatty acid oxidation and triglyceride/VLDL secretion. Cell Metab 3: 99-110

34. Mirebeau-Prunier D, Le Pennec S, Jacques C, Gueguen N, Poirier J, Malthiery Y, Savagner F (2010) Estrogen-related receptor alpha and PGC-1-related coactivator constitute a novel complex mediating the biogenesis of functional mitochondria. Febs J 277: 713-25

35. Andersson U, Scarpulla RC (2001) Pgc-1-related coactivator, a novel, serum-inducible coactivator of nuclear respiratory factor 1-dependent transcription in mammalian cells. Mol Cell Biol 21: 3738-49

36. Puigserver P, Adelmant G, Wu Z, Fan M, Xu J, O'Malley B, Spiegelman BM (1999) Activation of PPARgamma coactivator-1 through transcription factor docking. Science 286: 1368-71

37. Li S, Liu C, Li N, Hao T, Han T, Hill DE, Vidal M, Lin JD (2008) Genome-wide coactivation analysis of PGC-1alpha identifies BAF60a as a regulator of hepatic lipid metabolism. Cell Metab 8: 105-17

38. Wallberg AE, Yamamura S, Malik S, Spiegelman BM, Roeder RG (2003) Coordination of p300mediated chromatin remodeling and TRAP/mediator function through coactivator PGC1alpha. Mol Cell 12: 1137-49

39. Borgius L, Steffensen KR, Gustafsson JA, Treuter E (2002) Glucocorticoid signaling is perturbed by the atypical orphan receptor and corepressor SHP. J Biol Chem 277: 49761-6 
40. Xie YB, Park JH, Kim DK, Hwang JH, Oh S, Park SB, Shong M, Lee IK, Choi HS (2009) Transcriptional corepressor SMILE recruits SIRT1 to inhibit nuclear receptor estrogen receptor-related receptor gamma transactivation. J Biol Chem 284: 28762-74

41. Park YY, Ahn SW, Kim HJ, Kim JM, Lee IK, Kang H, Choi HS (2005) An autoregulatory loop controlling orphan nuclear receptor DAX-1 gene expression by orphan nuclear receptor ERRgamma. Nucleic Acids Res 33: 6756-68

42. Nedumaran B, Hong S, Xie YB, Kim YH, Seo WY, Lee MW, Lee CH, Koo SH, Choi HS (2009) DAX-1 acts as a novel corepressor of orphan nuclear receptor HNF4alpha and negatively regulates gluconeogenic enzyme gene expression. J Biol Chem 284: 27511-23

43. Monsalve M, Wu Z, Adelmant G, Puigserver P, Fan M, Spiegelman BM (2000) Direct coupling of transcription and mRNA processing through the thermogenic coactivator PGC-1. Mol Cell 6: 307-16

44. Meirhaeghe A, Crowley V, Lenaghan C, Lelliott C, Green K, Stewart A, Hart K, Schinner S, Sethi JK, Yeo G, Brand MD, Cortright RN, O'Rahilly S, Montague C, Vidal-Puig AJ (2003) Characterization of the human, mouse and rat PGC1 beta (peroxisome-proliferator-activated receptor-gamma co-activator 1 beta) gene in vitro and in vivo. Biochem J 373: 155-65

45. Zhang $Y$, Huypens $P$, Adamson AW, Chang JS, Henagan TM, Boudreau A, Lenard NR, Burk D, Klein J, Perwitz N, Shin J, Fasshauer M, Kralli A, Gettys TW (2009) Alternative mRNA splicing produces a novel biologically active short isoform of PGC-1alpha. J Biol Chem 284: 32813-26

46. Yoshioka T, Inagaki K, Noguchi T, Sakai M, Ogawa W, Hosooka T, Iguchi H, Watanabe E, Matsuki Y, Hiramatsu R, Kasuga M (2009) Identification and characterization of an alternative promoter of the human PGC-1alpha gene. Biochem Biophys Res Commun 381: 537-43

47. Miura S, Kai Y, Kamei Y, Ezaki O (2008) Isoform-specific increases in murine skeletal muscle peroxisome proliferator-activated receptor-gamma coactivator-1alpha (PGC-1alpha) mRNA in response to beta2-adrenergic receptor activation and exercise. Endocrinology 149: 452733

48. Ruas JL, White JP, Rao RR, Kleiner S, Brannan KT, Harrison BC, Greene NP, Wu J, Estall JL, Irving BA, Lanza IR, Rasbach KA, Okutsu M, Nair KS, Yan Z, Leinwand LA, Spiegelman BM (2012) A PGC-1alpha isoform induced by resistance training regulates skeletal muscle hypertrophy. Cell 151: 1319-31

49. Herzig S, Long F, Jhala US, Hedrick S, Quinn R, Bauer A, Rudolph D, Schutz G, Yoon C, Puigserver $P$, Spiegelman B, Montminy M (2001) CREB regulates hepatic gluconeogenesis through the coactivator PGC-1. Nature 413: 179-83

50. Handschin C, Rhee J, Lin J, Tarr PT, Spiegelman BM (2003) An autoregulatory loop controls peroxisome proliferator-activated receptor gamma coactivator 1alpha expression in muscle. Proc Natl Acad Sci U S A 100: 7111-6

51. Cao W, Collins QF, Becker TC, Robidoux J, Lupo EG, Jr., Xiong Y, Daniel KW, Floering L, Collins $S$ (2005) p38 Mitogen-activated protein kinase plays a stimulatory role in hepatic gluconeogenesis. J Biol Chem 280: 42731-7

52. Akimoto T, Pohnert SC, Li P, Zhang M, Gumbs C, Rosenberg PB, Williams RS, Yan Z (2005) Exercise stimulates Pgc-1alpha transcription in skeletal muscle through activation of the p38 MAPK pathway. J Biol Chem 280: 19587-93

53. Jager S, Handschin C, St-Pierre J, Spiegelman BM (2007) AMP-activated protein kinase (AMPK) action in skeletal muscle via direct phosphorylation of PGC-1alpha. Proc Natl Acad Sci U S A 104: 12017-22

54. Hondares E, Mora O, Yubero P, de la Concepcion MR, Iglesias R, Giralt M, Villarroya F (2006) Thiazolidinediones and rexinoids induce peroxisome proliferator-activated receptorcoactivator (PGC)-1alpha gene transcription: an autoregulatory loop controls PGC-1alpha expression in adipocytes via peroxisome proliferator-activated receptor-gamma coactivation. Endocrinology 147: 2829-38

55. Hondares E, Rosell M, Diaz-Delfin J, Olmos Y, Monsalve M, Iglesias R, Villarroya F, Giralt M (2011) Peroxisome proliferator-activated receptor alpha (PPARalpha) induces PPARgamma 
coactivator 1alpha (PGC-1alpha) gene expression and contributes to thermogenic activation of brown fat: involvement of PRDM16. J Biol Chem 286: 43112-22

56. Daitoku H, Yamagata K, Matsuzaki H, Hatta M, Fukamizu A (2003) Regulation of PGC-1 promoter activity by protein kinase $B$ and the forkhead transcription factor FKHR. Diabetes 52: $642-9$

57. Czubryt MP, McAnally J, Fishman GI, Olson EN (2003) Regulation of peroxisome proliferatoractivated receptor gamma coactivator 1alpha (PGC-1alpha) and mitochondrial function by MEF2 and HDAC5. Proc Natl Acad Sci U S A 100: 1711-6

58. Wang L, Liu J, Saha P, Huang J, Chan L, Spiegelman B, Moore DD (2005) The orphan nuclear receptor SHP regulates PGC-1alpha expression and energy production in brown adipocytes. Cell Metab 2: 227-38

59. Wu N, Yin L, Hanniman EA, Joshi S, Lazar MA (2009) Negative feedback maintenance of heme homeostasis by its receptor, Rev-erbalpha. Genes Dev 23: 2201-9

60. Barres R, Osler ME, Yan J, Rune A, Fritz T, Caidahl K, Krook A, Zierath JR (2009) Non-CpG methylation of the PGC-1alpha promoter through DNMT3B controls mitochondrial density. Cell Metab 10: 189-98

61. Puigserver P, Rhee J, Lin J, Wu Z, Yoon JC, Zhang C-Y, Krauss S, Mootha VK, Lowell BB, Spiegelman BM (2001) Cytokine Stimulation of Energy Expenditure through p38 MAP Kinase Activation of PPARgamma Coactivator-1. Mol Cell 8: 971-82

62. Fan M, Rhee J, St-Pierre J, Handschin C, Puigserver P, Lin J, Jaeger S, Erdjument-Bromage H, Tempst $P$, Spiegelman BM (2004) Suppression of mitochondrial respiration through recruitment of p160 myb binding protein to PGC-1alpha: modulation by p38 MAPK. Genes Dev 18: 278-89

63. Chang JS, Huypens P, Zhang Y, Black C, Kralli A, Gettys TW (2010) Regulation of NT-PGC1alpha subcellular localization and function by protein kinase A-dependent modulation of nuclear export by CRM1. J Biol Chem 285: 18039-50

64. Li X, Monks B, Ge Q, Birnbaum MJ (2007) Akt/PKB regulates hepatic metabolism by directly inhibiting PGC-1alpha transcription coactivator. Nature 447: 1012-6

65. Anderson RM, Barger JL, Edwards MG, Braun KH, O'Connor CE, Prolla TA, Weindruch R (2008) Dynamic regulation of PGC-1alpha localization and turnover implicates mitochondrial adaptation in calorie restriction and the stress response. Aging Cell 7: 101-11

66. Olson BL, Hock MB, Ekholm-Reed S, Wohlschlegel JA, Dev KK, Kralli A, Reed SI (2008) SCFCdc4 acts antagonistically to the PGC-1alpha transcriptional coactivator by targeting it for ubiquitin-mediated proteolysis. Genes Dev 22: 252-64

67. Lerin C, Rodgers JT, Kalume DE, Kim SH, Pandey A, Puigserver P (2006) GCN5 acetyltransferase complex controls glucose metabolism through transcriptional repression of PGC-1alpha. Cell Metab 3: 429-38

68. Rodgers JT, Lerin C, Haas W, Gygi SP, Spiegelman BM, Puigserver P (2005) Nutrient control of glucose homeostasis through a complex of PGC-1alpha and SIRT1. Nature 434: 113-8

69. Nemoto S, Fergusson MM, Finkel T (2005) SIRT1 functionally interacts with the metabolic regulator and transcriptional coactivator PGC-1\{alpha\}. J Biol Chem 280: 16456-60

70. Canto C, Auwerx J (2009) PGC-1alpha, SIRT1 and AMPK, an energy sensing network that controls energy expenditure. Curr Opin Lipidol 20: 98-105

71. Rytinki MM, Palvimo JJ (2009) SUMOylation attenuates the function of PGC-1alpha. J Biol Chem 284: 26184-93

72. Hallberg M, Morganstein DL, Kiskinis E, Shah K, Kralli A, Dilworth SM, White R, Parker MG, Christian M (2008) A functional interaction between RIP140 and PGC-1alpha regulates the expression of the lipid droplet protein CIDEA. Mol Cell Biol 28: 6785-95

73. Housley MP, Udeshi ND, Rodgers JT, Shabanowitz J, Puigserver P, Hunt DF, Hart GW (2009) A PGC-1alpha-O-GlcNAc transferase complex regulates FoxO transcription factor activity in response to glucose. J Biol Chem 284: 5148-57 
74. Teyssier C, Ma H, Emter R, Kralli A, Stallcup MR (2005) Activation of nuclear receptor coactivator PGC-1alpha by arginine methylation. Genes Dev 19: 1466-73

75. LeMoine CM, Lougheed SC, Moyes CD (2010) Modular evolution of PGC-1alpha in vertebrates. J Mol Evol 70: 492-505

76. Tiefenbock SK, Baltzer C, Egli NA, Frei C (2009) The Drosophila PGC-1 homologue Spargel coordinates mitochondrial activity to insulin signalling. Embo J

77. Schreiber SN, Emter R, Hock MB, Knutti D, Cardenas J, Podvinec M, Oakeley EJ, Kralli A (2004) The estrogen-related receptor alpha (ERRalpha) functions in PPARgamma coactivator 1alpha (PGC-1alpha)-induced mitochondrial biogenesis. Proc Natl Acad Sci U S A 101: 6472-7

78. Schreiber SN, Knutti D, Brogli K, UhImann T, Kralli A (2003) The transcriptional coactivator PGC-1 regulates the expression and activity of the orphan nuclear receptor estrogen-related receptor alpha (ERRalpha). J Biol Chem 278: 9013-8

79. Mootha VK, Handschin C, Arlow D, Xie X, St Pierre J, Sihag S, Yang W, Altshuler D, Puigserver P, Patterson N, Willy PJ, Schulman IG, Heyman RA, Lander ES, Spiegelman BM (2004) Erralpha and Gabpa/b specify PGC-1alpha-dependent oxidative phosphorylation gene expression that is altered in diabetic muscle. Proc Natl Acad Sci U S A 101: 6570-5

80. Lin J, Wu PH, Tarr PT, Lindenberg KS, St-Pierre J, Zhang CY, Mootha VK, Jager S, Vianna CR, Reznick RM, Cui L, Manieri M, Donovan MX, Wu Z, Cooper MP, Fan MC, Rohas LM, Zavacki AM, Cinti S, Shulman GI, Lowell BB, Krainc D, Spiegelman BM (2004) Defects in adaptive energy metabolism with CNS-linked hyperactivity in PGC-1alpha null mice. Cell 119: 121-35

81. Leone TC, Lehman JJ, Finck BN, Schaeffer PJ, Wende AR, Boudina S, Courtois M, Wozniak DF, Sambandam N, Bernal-Mizrachi C, Chen Z, Holloszy JO, Medeiros DM, Schmidt RE, Saffitz JE, Abel ED, Semenkovich CF, Kelly DP (2005) PGC-1alpha deficiency causes multi-system energy metabolic derangements: muscle dysfunction, abnormal weight control and hepatic steatosis. PLoS Biol 3: e101

82. Sonoda J, Mehl IR, Chong LW, Nofsinger RR, Evans RM (2007) PGC-1beta controls mitochondrial metabolism to modulate circadian activity, adaptive thermogenesis, and hepatic steatosis. Proc Natl Acad Sci U S A 104: 5223-8

83. Lelliott CJ, Medina-Gomez G, Petrovic N, Kis A, Feldmann HM, Bjursell M, Parker N, Curtis K, Campbell M, Hu P, Zhang D, Litwin SE, Zaha VG, Fountain KT, Boudina S, Jimenez-Linan M, Blount M, Lopez M, Meirhaeghe A, Bohlooly YM, Storlien L, Stromstedt M, Snaith M, Oresic $M$, Abel ED, Cannon B, Vidal-Puig A (2006) Ablation of PGC-1beta results in defective mitochondrial activity, thermogenesis, hepatic function, and cardiac performance. PLoS Biol 4: e369

84. St-Pierre J, Lin J, Krauss S, Tarr PT, Yang R, Newgard CB, Spiegelman BM (2003) Bioenergetic analysis of peroxisome proliferator-activated receptor gamma coactivators 1alpha and 1beta (PGC-1alpha and PGC-1beta) in muscle cells. J Biol Chem 278: 26597-603

85. St-Pierre J, Drori S, Uldry M, Silvaggi JM, Rhee J, Jager S, Handschin C, Zheng K, Lin J, Yang W, Simon DK, Bachoo R, Spiegelman BM (2006) Suppression of Reactive Oxygen Species and Neurodegeneration by the PGC-1 Transcriptional Coactivators. Cell 127: 397-408

86. Lin J, Tarr PT, Yang R, Rhee J, Puigserver P, Newgard CB, Spiegelman BM (2003) PGC-1beta in the regulation of hepatic glucose and energy metabolism. J Biol Chem 278: 30843-8

87. Bagattin A, Hugendubler L, Mueller E (2010) Transcriptional coactivator PGC-1alpha promotes peroxisomal remodeling and biogenesis. Proc Natl Acad Sci U S A 107: 20376-81

88. Lin J, Wu H, Tarr PT, Zhang CY, Wu Z, Boss O, Michael LF, Puigserver P, Isotani E, Olson EN, Lowell BB, Bassel-Duby R, Spiegelman BM (2002) Transcriptional co-activator PGC-1 alpha drives the formation of slow-twitch muscle fibres. Nature 418: 797-801

89. Arany Z, Lebrasseur N, Morris C, Smith E, Yang W, Ma Y, Chin S, Spiegelman BM (2007) The transcriptional coactivator PGC-1 beta drives the formation of oxidative type IIX fibers in skeletal muscle. Cell Metab 5: 35-46 
90. Terada S, Goto M, Kato M, Kawanaka K, Shimokawa T, Tabata I (2002) Effects of low-intensity prolonged exercise on PGC-1 mRNA expression in rat epitrochlearis muscle. Biochem Biophys Res Commun 296: 350-4

91. Goto M, Terada S, Kato M, Katoh M, Yokozeki T, Tabata I, Shimokawa T (2000) cDNA Cloning and mRNA analysis of PGC-1 in epitrochlearis muscle in swimming-exercised rats. Biochem Biophys Res Commun 274: 350-4

92. Pilegaard H, Saltin B, Neufer PD (2003) Exercise induces transient transcriptional activation of the PGC-1alpha gene in human skeletal muscle. J Physiol 546: 851-8

93. Wright DC, Han DH, Garcia-Roves PM, Geiger PC, Jones TE, Holloszy JO (2007) Exerciseinduced mitochondrial biogenesis begins before the increase in muscle PGC-1alpha expression. J Biol Chem 282: 194-9

94. Wende AR, Schaeffer PJ, Parker GJ, Zechner C, Han DH, Chen MM, Hancock CR, Lehman JJ, Huss JM, McClain DA, Holloszy JO, Kelly DP (2007) A role for the transcriptional coactivator PGC-1alpha in muscle refueling. J Biol Chem 282: 36642-51

95. Wende AR, Huss JM, Schaeffer PJ, Giguere V, Kelly DP (2005) PGC-1alpha coactivates PDK4 gene expression via the orphan nuclear receptor ERRalpha: a mechanism for transcriptional control of muscle glucose metabolism. Mol Cell Biol 25: 10684-94

96. Calvo JA, Daniels TG, Wang X, Paul A, Lin J, Spiegelman BM, Stevenson SC, Rangwala SM (2008) Muscle-specific expression of PPARgamma coactivator-1alpha improves exercise performance and increases peak oxygen uptake. J Appl Physiol 104: 1304-12

97. Summermatter S, Baum O, Santos G, Hoppeler H, Handschin C (2010) Peroxisome proliferator-activated receptor \{gamma\} coactivator 1 alpha\} (PGC-1\{alpha\}) promotes skeletal muscle lipid refueling in vivo by activating de novo lipogenesis and the pentose phosphate pathway. The Journal of biological chemistry 285: 32793-800

98. Summermatter S, Troxler H, Santos G, Handschin C (2011) Coordinated balancing of muscle oxidative metabolism through PGC-1alpha increases metabolic flexibility and preserves insulin sensitivity. Biochem Biophys Res Commun 408: 180-5

99. Silveira LR, Pilegaard H, Kusuhara K, Curi R, Hellsten Y (2006) The contraction induced increase in gene expression of peroxisome proliferator-activated receptor (PPAR)-gamma coactivator 1alpha (PGC-1alpha), mitochondrial uncoupling protein 3 (UCP3) and hexokinase II (HKII) in primary rat skeletal muscle cells is dependent on reactive oxygen species. Biochim Biophys Acta 1763: 969-76

100. Wenz T, Rossi SG, Rotundo RL, Spiegelman BM, Moraes CT (2009) Increased muscle PGC1alpha expression protects from sarcopenia and metabolic disease during aging. Proc Natl Acad Sci U S A 106: 20405-10

101. Handschin C, Kobayashi YM, Chin S, Seale P, Campbell KP, Spiegelman BM (2007) PGC-1alpha regulates the neuromuscular junction program and ameliorates Duchenne muscular dystrophy. Genes Dev 21: 770-83

102. Summermatter S, Thurnheer R, Santos G, Mosca B, Baum O, Treves S, Hoppeler H, Zorzato F, Handschin C (2012) Remodeling of calcium handling in skeletal muscle through PGC-1alpha: impact on force, fatigability, and fiber type. American journal of physiology. Cell physiology 302: C88-99

103. Arany Z, Foo SY, Ma Y, Ruas JL, Bommi-Reddy A, Girnun G, Cooper M, Laznik D, Chinsomboon J, Rangwala SM, Baek KH, Rosenzweig A, Spiegelman BM (2008) HIF-independent regulation of VEGF and angiogenesis by the transcriptional coactivator PGC-1alpha. Nature 451: 100812

104. Chinsomboon J, Ruas J, Gupta RK, Thom R, Shoag J, Rowe GC, Sawada N, Raghuram S, Arany $Z$ (2009) The transcriptional coactivator PGC-1alpha mediates exercise-induced angiogenesis in skeletal muscle. Proc Natl Acad Sci U S A 106: 21401-6

105. Handschin C, Chin S, Li P, Liu F, Maratos-Flier E, Lebrasseur NK, Yan Z, Spiegelman BM (2007) Skeletal muscle fiber-type switching, exercise intolerance, and myopathy in PGC-1alpha muscle-specific knock-out animals. J Biol Chem 282: 30014-21 
106. Zechner C, Lai L, Zechner JF, Geng T, Yan Z, Rumsey JW, Collia D, Chen Z, Wozniak DF, Leone TC, Kelly DP (2011) Total skeletal muscle PGC-1 deficiency uncouples mitochondrial derangements from fiber type determination and insulin sensitivity. Cell Metab 12: 633-42

107. Rowe GC, Jang C, Patten IS, Arany Z (2011) PGC-1 beta regulates angiogenesis in skeletal muscle. Am J Physiol Endocrinol Metab 301: E155-63

108. Chang JH, Lin KH, Shih CH, Chang YJ, Chi HC, Chen SL (2006) Myogenic basic helix-loop-helix proteins regulate the expression of peroxisomal proliferator activated receptor-gamma coactivator-1alpha. Endocrinology 147: 3093-106

109. Liu C, Li S, Liu T, Borjigin J, Lin JD (2007) Transcriptional coactivator PGC-1alpha integrates the mammalian clock and energy metabolism. Nature 447: 477-81

110. Andrews JL, Zhang X, McCarthy JJ, McDearmon EL, Hornberger TA, Russell B, Campbell KS, Arbogast S, Reid MB, Walker JR, Hogenesch JB, Takahashi JS, Esser KA (2010) CLOCK and BMAL1 regulate MyoD and are necessary for maintenance of skeletal muscle phenotype and function. Proc Natl Acad Sci U S A 107: 19090-5

111. Speckmann B, Walter PL, Alili L, Reinehr R, Sies H, Klotz LO, Steinbrenner H (2008) Selenoprotein $\mathrm{P}$ expression is controlled through interaction of the coactivator PGC-1alpha with FoxO1a and hepatocyte nuclear factor 4alpha transcription factors. Hepatology 48: 1998-2006

112. Handschin C, Lin J, Rhee J, Peyer AK, Chin S, Wu PH, Meyer UA, Spiegelman BM (2005) Nutritional regulation of hepatic heme biosynthesis and porphyria through PGC-1alpha. Cell 122: $505-15$

113. Shin DJ, Campos JA, Gil G, Osborne TF (2003) PGC-1alpha activates CYP7A1 and bile acid biosynthesis. J Biol Chem 278: 50047-52

114. Li S, Arning E, Liu C, Vitvitsky V, Hernandez C, Banerjee R, Bottiglieri T, Lin JD (2009) Regulation of homocysteine homeostasis through the transcriptional coactivator PGC-1alpha. Am J Physiol Endocrinol Metab 296: E543-8

115. Arany Z, He H, Lin J, Hoyer K, Handschin C, Toka O, Ahmad F, Matsui T, Chin S, Wu PH, Rybkin, II, Shelton JM, Manieri M, Cinti S, Schoen FJ, Bassel-Duby R, Rosenzweig A, Ingwall JS, Spiegelman BM (2005) Transcriptional coactivator PGC-1 alpha controls the energy state and contractile function of cardiac muscle. Cell Metab 1: 259-71

116. Arany Z, Novikov M, Chin S, Ma Y, Rosenzweig A, Spiegelman BM (2006) Transverse aortic constriction leads to accelerated heart failure in mice lacking PPAR-gamma coactivator 1alpha. Proc Natl Acad Sci U S A 103: 10086-91

117. Riehle C, Wende AR, Zaha VG, Pires KM, Wayment B, Olsen C, Bugger H, Buchanan J, Wang X, Moreira AB, Doenst T, Medina-Gomez G, Litwin SE, Lelliott CJ, Vidal-Puig A, Abel ED (2011) PGC-1beta deficiency accelerates the transition to heart failure in pressure overload hypertrophy. Circ Res 109: 783-93

118. Lai L, Leone TC, Zechner C, Schaeffer PJ, Kelly SM, Flanagan DP, Medeiros DM, Kovacs A, Kelly DP (2008) Transcriptional coactivators PGC-1alpha and PGC-lbeta control overlapping programs required for perinatal maturation of the heart. Genes Dev 22: 1948-61

119. Lehman JJ, Barger PM, Kovacs A, Saffitz JE, Medeiros DM, Kelly DP (2000) Peroxisome proliferator-activated receptor gamma coactivator-1 promotes cardiac mitochondrial biogenesis. J Clin Invest 106: 847-56

120. Uldry M, Yang W, St-Pierre J, Lin J, Seale P, Spiegelman BM (2006) Complementary action of the PGC-1 coactivators in mitochondrial biogenesis and brown fat differentiation. Cell Metab 3: 333-41

121. Kajimura S, Seale P, Tomaru T, Erdjument-Bromage H, Cooper MP, Ruas JL, Chin S, Tempst P, Lazar MA, Spiegelman BM (2008) Regulation of the brown and white fat gene programs through a PRDM16/CtBP transcriptional complex. Genes Dev 22: 1397-409

122. Tadaishi M, Miura S, Kai Y, Kano Y, Oishi Y, Ezaki O (2011) Skeletal muscle-specific expression of PGC-1alpha-b, an exercise-responsive isoform, increases exercise capacity and peak oxygen uptake. PLoS One 6: e28290 
123. Fisher FM, Kleiner S, Douris N, Fox EC, Mepani RJ, Verdeguer F, Wu J, Kharitonenkov A, Flier JS, Maratos-Flier E, Spiegelman BM (2012) FGF21 regulates PGC-1alpha and browning of white adipose tissues in adaptive thermogenesis. Genes Dev 26: 271-81

124. Scime A, Grenier G, Huh MS, Gillespie MA, Bevilacqua L, Harper ME, Rudnicki MA (2005) Rb and $\mathrm{p} 107$ regulate preadipocyte differentiation into white versus brown fat through repression of PGC-1alpha. Cell Metab 2: 283-95

125. Pan D, Fujimoto M, Lopes A, Wang YX (2009) Twist-1 is a PPARdelta-inducible, negativefeedback regulator of PGC-1alpha in brown fat metabolism. Cell 137: 73-86

126. Kleiner S, Mepani RJ, Laznik D, Ye L, Jurczak MJ, Jornayvaz FR, Estall JL, Chatterjee Bhowmick D, Shulman GI, Spiegelman BM (2012) Development of insulin resistance in mice lacking PGC1alpha in adipose tissues. Proceedings of the National Academy of Sciences of the United States of America 109: 9635-40

127. Yoon JC, Xu G, Deeney JT, Yang SN, Rhee J, Puigserver P, Levens AR, Yang R, Zhang CY, Lowell BB, Berggren PO, Newgard CB, Bonner-Weir S, Weir G, Spiegelman BM (2003) Suppression of beta cell energy metabolism and insulin release by PGC-1alpha. Dev Cell 5: 73-83

128. Ling C, Del Guerra S, Lupi R, Ronn T, Granhall C, Luthman H, Masiello P, Marchetti P, Groop L, Del Prato $S$ (2008) Epigenetic regulation of PPARGC1A in human type 2 diabetic islets and effect on insulin secretion. Diabetologia 51: 615-22

129. Wareski P, Vaarmann A, Choubey V, Safiulina D, Liiv J, Kuum M, Kaasik A (2009) PGC-1\{alpha\} and PGC-1 \{beta\} regulate mitochondrial density in neurons. J Biol Chem 284: 21379-85

130. Liang H, Ward WF, Jang YC, Bhattacharya A, Bokov AF, Li Y, Jernigan A, Richardson A, Van Remmen $H$ (2011) PGC-1alpha protects neurons and alters disease progression in an amyotrophic lateral sclerosis mouse model. Muscle Nerve 44: 947-56

131. Cui L, Jeong H, Borovecki F, Parkhurst CN, Tanese N, Krainc D (2006) Transcriptional repression of PGC-1alpha by mutant huntingtin leads to mitochondrial dysfunction and neurodegeneration. Cell 127: 59-69

132. Qin W, Haroutunian V, Katsel P, Cardozo CP, Ho L, Buxbaum JD, Pasinetti GM (2009) PGC1alpha expression decreases in the Alzheimer disease brain as a function of dementia. Arch Neurol 66: 352-61

133. Ma D, Li S, Lucas EK, Cowell RM, Lin JD (2010) Neuronal inactivation of peroxisome proliferator-activated receptor gamma coactivator 1alpha (PGC-1alpha) protects mice from diet-induced obesity and leads to degenerative lesions. J Biol Chem 285: 39087-95

134. Egger A, Samardzija M, Sothilingam V, Tanimoto N, Lange C, Salatino S, Fang L, GarciaGarrido M, Beck S, Okoniewski MJ, Neutzner A, Seeliger MW, Grimm C, Handschin C (2012) PGC-1alpha determines light damage susceptibility of the murine retina. PLoS One 7: e31272

135. Kawakami Y, Tsuda M, Takahashi S, Taniguchi N, Esteban CR, Zemmyo M, Furumatsu T, Lotz M, Belmonte JC, Asahara H (2005) Transcriptional coactivator PGC-1alpha regulates chondrogenesis via association with Sox9. Proc Natl Acad Sci U S A 102: 2414-9

136. Ishii KA, Fumoto T, Iwai K, Takeshita S, Ito M, Shimohata N, Aburatani H, Taketani S, Lelliott CJ, Vidal-Puig A, Ikeda K (2009) Coordination of PGC-1beta and iron uptake in mitochondrial biogenesis and osteoclast activation. Nat Med 15: 259-66

137. Vercauteren K, Pasko RA, Gleyzer N, Marino VM, Scarpulla RC (2006) PGC-1-related coactivator: immediate early expression and characterization of a CREB/NRF-1 binding domain associated with cytochrome $c$ promoter occupancy and respiratory growth. Mol Cell Biol 26: 7409-19

138. Sacheck JM, Hyatt JP, Raffaello A, Jagoe RT, Roy RR, Edgerton VR, Lecker SH, Goldberg AL (2007) Rapid disuse and denervation atrophy involve transcriptional changes similar to those of muscle wasting during systemic diseases. Faseb J 21: 140-55

139. Adhihetty PJ, O'Leary MF, Chabi B, Wicks KL, Hood DA (2007) Effect of denervation on mitochondrially mediated apoptosis in skeletal muscle. J Appl Physiol 102: 1143-51 
140. Sandri M, Lin J, Handschin C, Yang W, Arany ZP, Lecker SH, Goldberg AL, Spiegelman BM (2006) PGC-1alpha protects skeletal muscle from atrophy by suppressing FoxO3 action and atrophy-specific gene transcription. Proc Natl Acad Sci U S A 103: 16260-5

141. Hanai J, Cao P, Tanksale P, Imamura S, Koshimizu E, Zhao J, Kishi S, Yamashita M, Phillips PS, Sukhatme VP, Lecker SH (2007) The muscle-specific ubiquitin ligase atrogin-1/MAFbx mediates statin-induced muscle toxicity. J Clin Invest 117: 3940-51

142. Brault JJ, Jespersen JG, Goldberg AL (2010) Peroxisome proliferator-activated receptor gamma coactivator 1alpha or 1beta overexpression inhibits muscle protein degradation, induction of ubiquitin ligases, and disuse atrophy. J Biol Chem 285: 19460-71

143. Wenz T, Diaz F, Spiegelman BM, Moraes CT (2008) Activation of the PPAR/PGC-1alpha pathway prevents a bioenergetic deficit and effectively improves a mitochondrial myopathy phenotype. Cell Metab 8: 249-56

144. Wenz T, Diaz F, Hernandez D, Moraes CT (2009) Endurance exercise is protective for mice with mitochondrial myopathy. J Appl Physiol 106: 1712-9

145. Chaturvedi RK, Adhihetty P, Shukla S, Hennessy T, Calingasan N, Yang L, Starkov A, Kiaei M, Cannella M, Sassone J, Ciammola A, Squitieri F, Beal MF (2009) Impaired PGC-1alpha function in muscle in Huntington's disease. Hum Mol Genet 18: 3048-65

146. Crunkhorn S, Dearie F, Mantzoros C, Gami H, da Silva WS, Espinoza D, Faucette R, Barry K, Bianco AC, Patti ME (2007) Peroxisome proliferator activator receptor gamma coactivator-1 expression is reduced in obesity: potential pathogenic role of saturated fatty acids and p38 mitogen-activated protein kinase activation. J Biol Chem 282: 15439-50

147. Mootha VK, Lindgren CM, Eriksson KF, Subramanian A, Sihag S, Lehar J, Puigserver P, Carlsson E, Ridderstrale M, Laurila E, Houstis N, Daly MJ, Patterson N, Mesirov JP, Golub TR, Tamayo P, Spiegelman BM, Lander ES, Hirschhorn JN, Altshuler D, Groop LC (2003) PGC-1alpharesponsive genes involved in oxidative phosphorylation are coordinately downregulated in human diabetes. Nat Genet 34: 267-73

148. Patti ME, Butte AJ, Crunkhorn S, Cusi K, Berria R, Kashyap S, Miyazaki Y, Kohane I, Costello M, Saccone R, Landaker EJ, Goldfine AB, Mun E, DeFronzo R, Finlayson J, Kahn CR, Mandarino LJ (2003) Coordinated reduction of genes of oxidative metabolism in humans with insulin resistance and diabetes: Potential role of PGC1 and NRF1. Proc Natl Acad Sci U S A 100: 846671

149. Morino K, Petersen KF, Dufour S, Befroy D, Frattini J, Shatzkes N, Neschen S, White MF, Bilz S, Sono S, Pypaert M, Shulman GI (2005) Reduced mitochondrial density and increased IRS-1 serine phosphorylation in muscle of insulin-resistant offspring of type 2 diabetic parents. J Clin Invest 115: 3587-93

150. Benton CR, Nickerson JG, Lally J, Han XX, Holloway GP, Glatz JF, Luiken JJ, Graham TE, Heikkila $\mathrm{JJ}$, Bonen A (2008) Modest PGC-1alpha overexpression in muscle in vivo is sufficient to increase insulin sensitivity and palmitate oxidation in subsarcolemmal, not intermyofibrillar, mitochondria. J Biol Chem 283: 4228-40

151. Handschin C, Choi CS, Chin S, Kim S, Kawamori D, Kurpad AJ, Neubauer N, Hu J, Mootha VK, Kim YB, Kulkarni RN, Shulman GI, Spiegelman BM (2007) Abnormal glucose homeostasis in skeletal muscle-specific PGC-1alpha knockout mice reveals skeletal muscle-pancreatic beta cell crosstalk. J Clin Invest 117: 3463-74

152. Choi CS, Befroy DE, Codella R, Kim S, Reznick RM, Hwang YJ, Liu ZX, Lee HY, Distefano A, Samuel VT, Zhang D, Cline GW, Handschin C, Lin J, Petersen KF, Spiegelman BM, Shulman GI (2008) Paradoxical effects of increased expression of PGC-1alpha on muscle mitochondrial function and insulin-stimulated muscle glucose metabolism. Proc Natl Acad Sci U S A 105: 19926-31

153. Ling C, Poulsen $P$, Carlsson E, Ridderstrale M, Almgren P, Wojtaszewski J, Beck-Nielsen $\mathrm{H}$, Groop L, Vaag A (2004) Multiple environmental and genetic factors influence skeletal muscle PGC-1alpha and PGC-1beta gene expression in twins. J Clin Invest 114: 1518-26 
154. Ek J, Andersen G, Urhammer SA, Gaede PH, Drivsholm T, Borch-Johnsen K, Hansen T, Pedersen $O$ (2001) Mutation analysis of peroxisome proliferator-activated receptor-gamma coactivator-1 (PGC-1) and relationships of identified amino acid polymorphisms to Type II diabetes mellitus. Diabetologia 44: 2220-6

155. Lacquemant C, Chikri M, Boutin P, Samson C, Froguel P (2002) No association between the G482S polymorphism of the proliferator-activated receptor- gamma coactivator-1 (PGC-1) gene and Type II diabetes in French Caucasias. Diabetologia 45: 602-3; discussion 4

156. Nitz I, Ewert A, Klapper M, Doring F (2007) Analysis of PGC-1alpha variants Gly482Ser and Thr612Met concerning their PPARgamma2-coactivation function. Biochem Biophys Res Commun 353: 481-6

157. Kim JH, Shin HD, Park BL, Cho YM, Kim SY, Lee HK, Park KS (2005) Peroxisome proliferatoractivated receptor gamma coactivator 1 alpha promoter polymorphisms are associated with early-onset type 2 diabetes mellitus in the Korean population. Diabetologia 48: 1323-30

158. Oberkofler H, Linnemayr V, Weitgasser R, Klein K, Xie M, Iglseder B, Krempler F, Paulweber B, Patsch W (2004) Complex haplotypes of the PGC-1alpha gene are associated with carbohydrate metabolism and type 2 diabetes. Diabetes 53: 1385-93

159. Vianna CR, Huntgeburth M, Coppari R, Choi CS, Lin J, Krauss S, Barbatelli G, Tzameli I, Kim YB, Cinti S, Shulman GI, Spiegelman BM, Lowell BB (2006) Hypomorphic mutation of PGC-1beta causes mitochondrial dysfunction and liver insulin resistance. Cell Metab 4: 453-64

160. Andersen G, Wegner L, Yanagisawa K, Rose CS, Lin J, Glumer C, Drivsholm T, Borch-Johnsen K, Jorgensen T, Hansen T, Spiegelman BM, Pedersen O (2005) Evidence of an association between genetic variation of the coactivator PGC-1beta and obesity. J Med Genet 42: 402-7

161. Ling C, Wegner L, Andersen G, Almgren P, Hansen T, Pedersen O, Groop L, Vaag A, Poulsen P (2007) Impact of the peroxisome proliferator activated receptor-gamma coactivator-1beta (PGC-1beta) Ala203Pro polymorphism on in vivo metabolism, PGC-1beta expression and fibre type composition in human skeletal muscle. Diabetologia 50: 1615-20

162. Baur JA, Pearson KJ, Price NL, Jamieson HA, Lerin C, Kalra A, Prabhu VV, Allard JS, Lopez-Lluch G, Lewis K, Pistell PJ, Poosala S, Becker KG, Boss O, Gwinn D, Wang M, Ramaswamy S, Fishbein KW, Spencer RG, Lakatta EG, Le Couteur D, Shaw RJ, Navas P, Puigserver P, Ingram DK, de Cabo R, Sinclair DA (2006) Resveratrol improves health and survival of mice on a highcalorie diet. Nature 444: 337-42

163. Lagouge M, Argmann C, Gerhart-Hines Z, Meziane H, Lerin C, Daussin F, Messadeq N, Milne J, Lambert P, Elliott P, Geny B, Laakso M, Puigserver P, Auwerx J (2006) Resveratrol improves mitochondrial function and protects against metabolic disease by activating SIRT1 and PGC1alpha. Cell 127: 1109-22

164. Pagel-Langenickel I, Bao J, Joseph JJ, Schwartz DR, Mantell BS, Xu X, Raghavachari N, Sack MN (2008) PGC-1alpha integrates insulin signaling, mitochondrial regulation, and bioenergetic function in skeletal muscle. J Biol Chem 283: 22464-72

165. Handschin C (2009) The biology of PGC-1alpha and its therapeutic potential. Trends in pharmacological sciences 30: 322-9

166. Seruga B, Zhang H, Bernstein LJ, Tannock IF (2008) Cytokines and their relationship to the symptoms and outcome of cancer. Nature reviews. Cancer 8: 887-99

167. Kawai T, Akira S (2010) The role of pattern-recognition receptors in innate immunity: update on Toll-like receptors. Nat Immunol 11: 373-84

168. Hayden MS, Ghosh S (2012) NF-kappaB, the first quarter-century: remarkable progress and outstanding questions. Genes \& development 26: 203-34

169. Hoffmann A, Levchenko A, Scott ML, Baltimore D (2002) The IkappaB-NF-kappaB signaling module: temporal control and selective gene activation. Science 298: 1241-5

170. Brown K, Park S, Kanno T, Franzoso G, Siebenlist U (1993) Mutual regulation of the transcriptional activator NF-kappa B and its inhibitor, I kappa B-alpha. Proc Natl Acad Sci U S A 90: 2532-6 
171. Mercurio F, Zhu H, Murray BW, Shevchenko A, Bennett BL, Li J, Young DB, Barbosa M, Mann M, Manning A, Rao A (1997) IKK-1 and IKK-2: cytokine-activated IkappaB kinases essential for NF-kappaB activation. Science 278: 860-6

172. Senftleben U, Cao Y, Xiao G, Greten FR, Krahn G, Bonizzi G, Chen Y, Hu Y, Fong A, Sun SC, Karin M (2001) Activation by IKKalpha of a second, evolutionary conserved, NF-kappa B signaling pathway. Science 293: 1495-9

173. Xiao G, Harhaj EW, Sun SC (2001) NF-kappaB-inducing kinase regulates the processing of NFkappaB2 p100. Mol Cell 7: 401-9

174. Coope HJ, Atkinson PG, Huhse B, Belich M, Janzen J, Holman MJ, Klaus GG, Johnston LH, Ley SC (2002) CD40 regulates the processing of NF-kappaB2 p100 to p52. Embo J 21: 5375-85

175. Dejardin E, Droin NM, Delhase M, Haas E, Cao Y, Makris C, Li ZW, Karin M, Ware CF, Green DR (2002) The lymphotoxin-beta receptor induces different patterns of gene expression via two NF-kappaB pathways. Immunity 17: 525-35

176. Claudio E, Brown K, Park S, Wang H, Siebenlist U (2002) BAFF-induced NEMO-independent processing of NF-kappa B2 in maturing B cells. Nat Immunol 3: 958-65

177. Brenner DA, O'Hara M, Angel P, Chojkier M, Karin M (1989) Prolonged activation of jun and collagenase genes by tumour necrosis factor-alpha. Nature 337: 661-3

178. Wagner EF, Eferl R (2005) Fos/AP-1 proteins in bone and the immune system. Immunological reviews 208: 126-40

179. Honda K, Taniguchi T (2006) IRFs: master regulators of signalling by Toll-like receptors and cytosolic pattern-recognition receptors. Nature reviews. Immunology 6: 644-58

180. Ryo A, Suizu F, Yoshida Y, Perrem K, Liou YC, Wulf G, Rottapel R, Yamaoka S, Lu KP (2003) Regulation of NF-kappaB signaling by Pin1-dependent prolyl isomerization and ubiquitinmediated proteolysis of p65/RelA. Mol Cell 12: 1413-26

181. Lee EG, Boone DL, Chai S, Libby SL, Chien M, Lodolce JP, Ma A (2000) Failure to regulate TNFinduced NF-kappaB and cell death responses in A20-deficient mice. Science 289: 2350-4

182. Wertz IE, O'Rourke KM, Zhou H, Eby M, Aravind L, Seshagiri S, Wu P, Wiesmann C, Baker R, Boone DL, Ma A, Koonin EV, Dixit VM (2004) De-ubiquitination and ubiquitin ligase domains of A20 downregulate NF-kappaB signalling. Nature 430: 694-9

183. Sizemore N, Lerner N, Dombrowski N, Sakurai H, Stark GR (2002) Distinct roles of the Ikappa $B$ kinase alpha and beta subunits in liberating nuclear factor kappa B (NF-kappa B) from Ikappa B and in phosphorylating the p65 subunit of NF-kappa B. J Biol Chem 277: 3863-9

184. Chew J, Biswas S, Shreeram S, Humaidi M, Wong ET, Dhillion MK, Teo H, Hazra A, Fang CC, Lopez-Collazo E, Bulavin DV, Tergaonkar V (2009) WIP1 phosphatase is a negative regulator of NF-kappaB signalling. Nat Cell Biol 11: 659-66

185. Staels B, Koenig W, Habib A, Merval R, Lebret M, Torra IP, Delerive P, Fadel A, Chinetti G, Fruchart JC, Najib J, Maclouf J, Tedgui A (1998) Activation of human aortic smooth-muscle cells is inhibited by PPARalpha but not by PPARgamma activators. Nature 393: 790-3

186. Marx N, Sukhova GK, Collins T, Libby P, Plutzky J (1999) PPARalpha activators inhibit cytokineinduced vascular cell adhesion molecule-1 expression in human endothelial cells. Circulation 99: 3125-31

187. Delerive P, De Bosscher K, Besnard S, Vanden Berghe W, Peters JM, Gonzalez FJ, Fruchart JC, Tedgui A, Haegeman G, Staels B (1999) Peroxisome proliferator-activated receptor alpha negatively regulates the vascular inflammatory gene response by negative cross-talk with transcription factors NF-kappaB and AP-1. J Biol Chem 274: 32048-54

188. Jiang C, Ting AT, Seed B (1998) PPAR-gamma agonists inhibit production of monocyte inflammatory cytokines. Nature 391: 82-6

189. Ricote M, Li AC, Willson TM, Kelly CJ, Glass CK (1998) The peroxisome proliferator-activated receptor-gamma is a negative regulator of macrophage activation. Nature 391: 79-82

190. Schule R, Rangarajan P, Kliewer S, Ransone L, Bolado J, Yang N, Verma IM, Evans RM (1990) Functional antagonism between oncoprotein c-Jun and the glucocorticoid receptor. Cell 62: 1217-26 
191. Jonat C, Rahmsdorf HJ, Park KK, Cato AC, Gebel S, Ponta H, Herrlich P (1990) Antitumor promotion and antiinflammation: down-modulation of AP-1 (Fos/Jun) activity by glucocorticoid hormone. Cell 62: 1189-204

192. Auphan N, DiDonato JA, Rosette C, Helmberg A, Karin M (1995) Immunosuppression by glucocorticoids: inhibition of NF-kappa B activity through induction of I kappa B synthesis. Science 270: 286-90

193. Scheinman RI, Cogswell PC, Lofquist AK, Baldwin AS, Jr. (1995) Role of transcriptional activation of I kappa B alpha in mediation of immunosuppression by glucocorticoids. Science 270: $283-6$

194. Delerive P, De Bosscher K, Vanden Berghe W, Fruchart JC, Haegeman G, Staels B (2002) DNA binding-independent induction of IkappaBalpha gene transcription by PPARalpha. Mol Endocrinol 16: 1029-39

195. Kamei Y, Xu L, Heinzel T, Torchia J, Kurokawa R, Gloss B, Lin SC, Heyman RA, Rose DW, Glass CK, Rosenfeld MG (1996) A CBP integrator complex mediates transcriptional activation and AP-1 inhibition by nuclear receptors. Cell 85: 403-14

196. Sheppard KA, Phelps KM, Williams AJ, Thanos D, Glass CK, Rosenfeld MG, Gerritsen ME, Collins T (1998) Nuclear integration of glucocorticoid receptor and nuclear factor-kappaB signaling by CREB-binding protein and steroid receptor coactivator-1. J Biol Chem 273: 29291-4

197. Ogawa S, Lozach J, Benner C, Pascual G, Tangirala RK, Westin S, Hoffmann A, Subramaniam S, David M, Rosenfeld MG, Glass CK (2005) Molecular determinants of crosstalk between nuclear receptors and toll-like receptors. Cell 122: 707-21

198. Kassel O, Schneider S, Heilbock C, Litfin M, Gottlicher M, Herrlich P (2004) A nuclear isoform of the focal adhesion LIM-domain protein Trip6 integrates activating and repressing signals at AP-1- and NF-kappaB-regulated promoters. Genes Dev 18: 2518-28

199. Rogatsky I, Luecke HF, Leitman DC, Yamamoto KR (2002) Alternate surfaces of transcriptional coregulator GRIP1 function in different glucocorticoid receptor activation and repression contexts. Proc Natl Acad Sci U S A 99: 16701-6

200. Saijo K, Winner B, Carson CT, Collier JG, Boyer L, Rosenfeld MG, Gage FH, Glass CK (2009) A Nurr1/CoREST pathway in microglia and astrocytes protects dopaminergic neurons from inflammation-induced death. Cell 137: 47-59

201. Pascual G, Fong AL, Ogawa S, Gamliel A, Li AC, Perissi V, Rose DW, Willson TM, Rosenfeld MG, Glass CK (2005) A SUMOylation-dependent pathway mediates transrepression of inflammatory response genes by PPAR-gamma. Nature 437: 759-63

202. Ghisletti S, Huang W, Ogawa S, Pascual G, Lin ME, Willson TM, Rosenfeld MG, Glass CK (2007) Parallel SUMOylation-dependent pathways mediate gene- and signal-specific transrepression by LXRs and PPARgamma. Mol Cell 25: 57-70

203. Lee JH, Park SM, Kim OS, Lee CS, Woo JH, Park SJ, Joe EH, Jou I (2009) Differential SUMOylation of LXRalpha and LXRbeta mediates transrepression of STAT1 inflammatory signaling in IFN-gamma-stimulated brain astrocytes. Mol Cell 35: 806-17

204. Delerive P, Martin-Nizard F, Chinetti G, Trottein F, Fruchart JC, Najib J, Duriez P, Staels B (1999) Peroxisome proliferator-activated receptor activators inhibit thrombin-induced endothelin-1 production in human vascular endothelial cells by inhibiting the activator protein-1 signaling pathway. Circ Res 85: 394-402

205. Nissen RM, Yamamoto KR (2000) The glucocorticoid receptor inhibits NFkappaB by interfering with serine-2 phosphorylation of the RNA polymerase II carboxy-terminal domain. Genes Dev 14: 2314-29

206. Luecke HF, Yamamoto KR (2005) The glucocorticoid receptor blocks P-TEFb recruitment by NFkappaB to effect promoter-specific transcriptional repression. Genes Dev 19: 1116-27

207. Ito K, Barnes PJ, Adcock IM (2000) Glucocorticoid receptor recruitment of histone deacetylase 2 inhibits interleukin-1beta-induced histone $\mathrm{H} 4$ acetylation on lysines 8 and 12 . Mol Cell Biol 20: 6891-903 
208. Ito K, Yamamura S, Essilfie-Quaye S, Cosio B, Ito M, Barnes PJ, Adcock IM (2006) Histone deacetylase 2-mediated deacetylation of the glucocorticoid receptor enables NF-kappaB suppression. J Exp Med 203: 7-13

209. Odegaard JI, Chawla A (2011) Alternative macrophage activation and metabolism. Annu Rev Pathol 6: 275-97

210. Hotamisligil GS, Arner P, Caro JF, Atkinson RL, Spiegelman BM (1995) Increased adipose tissue expression of tumor necrosis factor-alpha in human obesity and insulin resistance. $J$ Clin Invest 95: 2409-15

211. Hotamisligil GS, Peraldi P, Budavari A, Ellis R, White MF, Spiegelman BM (1996) IRS-1mediated inhibition of insulin receptor tyrosine kinase activity in TNF-alpha- and obesityinduced insulin resistance. Science 271: 665-8

212. Hirosumi J, Tuncman G, Chang L, Gorgun CZ, Uysal KT, Maeda K, Karin M, Hotamisligil GS (2002) A central role for JNK in obesity and insulin resistance. Nature 420: 333-6

213. Uysal KT, Wiesbrock SM, Marino MW, Hotamisligil GS (1997) Protection from obesityinduced insulin resistance in mice lacking TNF-alpha function. Nature 389: 610-4

214. Shi H, Kokoeva MV, Inouye K, Tzameli I, Yin H, Flier JS (2006) TLR4 links innate immunity and fatty acid-induced insulin resistance. J Clin Invest 116: 3015-25

215. Furukawa S, Fujita T, Shimabukuro M, Iwaki M, Yamada Y, Nakajima Y, Nakayama O, Makishima M, Matsuda M, Shimomura I (2004) Increased oxidative stress in obesity and its impact on metabolic syndrome. J Clin Invest 114: 1752-61

216. Ozcan U, Cao Q, Yilmaz E, Lee AH, Iwakoshi NN, Ozdelen E, Tuncman G, Gorgun C, Glimcher LH, Hotamisligil GS (2004) Endoplasmic reticulum stress links obesity, insulin action, and type 2 diabetes. Science 306: 457-61

217. Rutkowski JM, Davis KE, Scherer PE (2009) Mechanisms of obesity and related pathologies: the macro- and microcirculation of adipose tissue. Febs J 276: 5738-46

218. Cinti S, Mitchell G, Barbatelli G, Murano I, Ceresi E, Faloia E, Wang S, Fortier M, Greenberg AS, Obin MS (2005) Adipocyte death defines macrophage localization and function in adipose tissue of obese mice and humans. J Lipid Res 46: 2347-55

219. Kang K, Reilly SM, Karabacak V, Gangl MR, Fitzgerald K, Hatano B, Lee CH (2008) Adipocytederived Th2 cytokines and myeloid PPARdelta regulate macrophage polarization and insulin sensitivity. Cell Metab 7: 485-95

220. Ohashi K, Parker JL, Ouchi N, Higuchi A, Vita JA, Gokce N, Pedersen AA, Kalthoff C, Tullin S, Sams A, Summer R, Walsh K (2010) Adiponectin promotes macrophage polarization toward an anti-inflammatory phenotype. J Biol Chem 285: 6153-60

221. Kien CL (2009) Dietary interventions for metabolic syndrome: role of modifying dietary fats. Curr Diab Rep 9: 43-50

222. Odegaard JI, Ricardo-Gonzalez RR, Goforth MH, Morel CR, Subramanian V, Mukundan L, Red Eagle A, Vats D, Brombacher F, Ferrante AW, Chawla A (2007) Macrophage-specific PPARgamma controls alternative activation and improves insulin resistance. Nature 447: 1116-20

223. Vats D, Mukundan L, Odegaard JI, Zhang L, Smith KL, Morel CR, Wagner RA, Greaves DR, Murray PJ, Chawla A (2006) Oxidative metabolism and PGC-1beta attenuate macrophagemediated inflammation. Cell Metab 4: 13-24

224. Weisberg SP, McCann D, Desai M, Rosenbaum M, Leibel RL, Ferrante AW, Jr. (2003) Obesity is associated with macrophage accumulation in adipose tissue. J Clin Invest 112: 1796-808

225. Xu H, Barnes GT, Yang Q, Tan G, Yang D, Chou CJ, Sole J, Nichols A, Ross JS, Tartaglia LA, Chen $H(2003)$ Chronic inflammation in fat plays a crucial role in the development of obesityrelated insulin resistance. J Clin Invest 112: 1821-30

226. Lumeng CN, Bodzin JL, Saltiel AR (2007) Obesity induces a phenotypic switch in adipose tissue macrophage polarization. J Clin Invest 117: 175-84

227. Kamei N, Tobe K, Suzuki R, Ohsugi M, Watanabe T, Kubota N, Ohtsuka-Kowatari N, Kumagai K, Sakamoto K, Kobayashi M, Yamauchi T, Ueki K, Oishi Y, Nishimura S, Manabe I, Hashimoto 
H, Ohnishi Y, Ogata H, Tokuyama K, Tsunoda M, Ide T, Murakami K, Nagai R, Kadowaki T (2006) Overexpression of monocyte chemoattractant protein-1 in adipose tissues causes macrophage recruitment and insulin resistance. J Biol Chem 281: 26602-14

228. Kanda H, Tateya S, Tamori Y, Kotani K, Hiasa K, Kitazawa R, Kitazawa S, Miyachi H, Maeda S, Egashira K, Kasuga M (2006) MCP-1 contributes to macrophage infiltration into adipose tissue, insulin resistance, and hepatic steatosis in obesity. J Clin Invest 116: 1494-505

229. Weisberg SP, Hunter D, Huber R, Lemieux J, Slaymaker S, Vaddi K, Charo I, Leibel RL, Ferrante AW, Jr. (2006) CCR2 modulates inflammatory and metabolic effects of high-fat feeding. J Clin Invest 116: 115-24

230. Saberi M, Woods NB, de Luca C, Schenk S, Lu JC, Bandyopadhyay G, Verma IM, Olefsky JM (2009) Hematopoietic cell-specific deletion of toll-like receptor 4 ameliorates hepatic and adipose tissue insulin resistance in high-fat-fed mice. Cell Metab 10: 419-29

231. Solinas G, Vilcu C, Neels JG, Bandyopadhyay GK, Luo JL, Naugler W, Grivennikov S, WynshawBoris A, Scadeng M, Olefsky JM, Karin M (2007) JNK1 in hematopoietically derived cells contributes to diet-induced inflammation and insulin resistance without affecting obesity. Cell Metab 6: 386-97

232. Arkan MC, Hevener AL, Greten FR, Maeda S, Li ZW, Long JM, Wynshaw-Boris A, Poli G, Olefsky J, Karin M (2005) IKK-beta links inflammation to obesity-induced insulin resistance. Nat Med 11: 191-8

233. Wu D, Molofsky AB, Liang HE, Ricardo-Gonzalez RR, Jouihan HA, Bando JK, Chawla A, Locksley RM (2011) Eosinophils sustain adipose alternatively activated macrophages associated with glucose homeostasis. Science 332: 243-7

234. Winer S, Chan Y, Paltser G, Truong D, Tsui H, Bahrami J, Dorfman R, Wang Y, Zielenski J, Mastronardi F, Maezawa Y, Drucker DJ, Engleman E, Winer D, Dosch HM (2009) Normalization of obesity-associated insulin resistance through immunotherapy. Nat Med 15: 921-9

235. Feuerer M, Herrero L, Cipolletta D, Naaz A, Wong J, Nayer A, Lee J, Goldfine AB, Benoist C, Shoelson S, Mathis D (2009) Lean, but not obese, fat is enriched for a unique population of regulatory $T$ cells that affect metabolic parameters. Nat Med 15: 930-9

236. Rocha VZ, Folco EJ, Sukhova G, Shimizu K, Gotsman I, Vernon AH, Libby P (2008) Interferongamma, a Th1 cytokine, regulates fat inflammation: a role for adaptive immunity in obesity. Circ Res 103: 467-76

237. Elgazar-Carmon V, Rudich A, Hadad N, Levy R (2008) Neutrophils transiently infiltrate intraabdominal fat early in the course of high-fat feeding. J Lipid Res 49: 1894-903

238. Nishimura S, Manabe I, Nagasaki M, Eto K, Yamashita H, Ohsugi M, Otsu M, Hara K, Ueki K, Sugiura S, Yoshimura K, Kadowaki T, Nagai R (2009) CD8+ effector T cells contribute to macrophage recruitment and adipose tissue inflammation in obesity. Nat Med 15: 914-20

239. Winer DA, Winer S, Shen L, Wadia PP, Yantha J, Paltser G, Tsui H, Wu P, Davidson MG, Alonso MN, Leong HX, Glassford A, Caimol M, Kenkel JA, Tedder TF, McLaughlin T, Miklos DB, Dosch $H M$, Engleman EG (2011) B cells promote insulin resistance through modulation of T cells and production of pathogenic IgG antibodies. Nat Med 17: 610-7

240. Ilan Y, Maron R, Tukpah AM, Maioli TU, Murugaiyan G, Yang K, Wu HY, Weiner HL (2010) Induction of regulatory $T$ cells decreases adipose inflammation and alleviates insulin resistance in ob/ob mice. Proc Natl Acad Sci U S A 107: 9765-70

241. Eguchi K, Manabe I, Oishi-Tanaka Y, Ohsugi M, Kono N, Ogata F, Yagi N, Ohto U, Kimoto M, Miyake K, Tobe K, Arai H, Kadowaki T, Nagai R (2012) Saturated fatty acid and TLR signaling link beta cell dysfunction and islet inflammation. Cell Metab 15: 518-33

242. Patsouris D, Li PP, Thapar D, Chapman J, Olefsky JM, Neels JG (2008) Ablation of CD11Cpositive cells normalizes insulin sensitivity in obese insulin resistant animals. Cell Metab 8: 301-9

243. Hevener AL, Olefsky JM, Reichart D, Nguyen MT, Bandyopadyhay G, Leung HY, Watt MJ, Benner C, Febbraio MA, Nguyen AK, Folian B, Subramaniam S, Gonzalez FJ, Glass CK, Ricote 
M (2007) Macrophage PPAR gamma is required for normal skeletal muscle and hepatic insulin sensitivity and full antidiabetic effects of thiazolidinediones. J Clin Invest 117: 1658-69

244. Baeza-Raja B, Munoz-Canoves P (2004) p38 MAPK-induced nuclear factor-kappaB activity is required for skeletal muscle differentiation: role of interleukin-6. Mol Biol Cell 15: 2013-26

245. Canicio J, Ruiz-Lozano P, Carrasco M, Palacin M, Chien K, Zorzano A, Kaliman P (2001) Nuclear factor kappa B-inducing kinase and Ikappa B kinase-alpha signal skeletal muscle cell differentiation. J Biol Chem 276: 20228-33

246. Conejo R, Valverde AM, Benito M, Lorenzo M (2001) Insulin produces myogenesis in C2C12 myoblasts by induction of NF-kappaB and downregulation of AP-1 activities. J Cell Physiol 186: 82-94

247. Lehtinen SK, Rahkila P, Helenius M, Korhonen P, Salminen A (1996) Down-regulation of transcription factors AP-1, Sp-1, and NF-kappa B precedes myocyte differentiation. Biochem Biophys Res Commun 229: 36-43

248. Dogra C, Changotra H, Mohan S, Kumar A (2006) Tumor necrosis factor-like weak inducer of apoptosis inhibits skeletal myogenesis through sustained activation of nuclear factor-kappaB and degradation of MyoD protein. J Biol Chem 281: 10327-36

249. Bakkar N, Wang J, Ladner KJ, Wang H, Dahlman JM, Carathers M, Acharyya S, Rudnicki MA, Hollenbach AD, Guttridge DC (2008) IKK/NF-kappaB regulates skeletal myogenesis via a signaling switch to inhibit differentiation and promote mitochondrial biogenesis. J Cell Biol 180: 787-802

250. Guttridge DC, Albanese C, Reuther JY, Pestell RG, Baldwin AS, Jr. (1999) NF-kappaB controls cell growth and differentiation through transcriptional regulation of cyclin D1. Mol Cell Biol 19: $5785-99$

251. Dahlman JM, Wang J, Bakkar N, Guttridge DC (2009) The RelA/p65 subunit of NF-kappaB specifically regulates cyclin D1 protein stability: implications for cell cycle withdrawal and skeletal myogenesis. J Cell Biochem 106: 42-51

252. Wang H, Hertlein E, Bakkar N, Sun H, Acharyya S, Wang J, Carathers M, Davuluri R, Guttridge DC (2007) NF-kappaB regulation of YY1 inhibits skeletal myogenesis through transcriptional silencing of myofibrillar genes. Mol Cell Biol 27: 4374-87

253. Bakkar N, Ladner K, Canan BD, Liyanarachchi S, Bal NC, Pant M, Periasamy M, Li Q, Janssen PM, Guttridge DC (2012) IKKalpha and alternative NF-kappaB regulate PGC-1beta to promote oxidative muscle metabolism. J Cell Biol 196: 497-511

254. Ho RC, Hirshman MF, Li Y, Cai D, Farmer JR, Aschenbach WG, Witczak CA, Shoelson SE, Goodyear L (2005) Regulation of IkappaB kinase and NF-kappaB in contracting adult rat skeletal muscle. Am J Physiol Cell Physiol 289: C794-801

255. Ji LL, Gomez-Cabrera MC, Steinhafel N, Vina J (2004) Acute exercise activates nuclear factor (NF)-kappaB signaling pathway in rat skeletal muscle. Faseb J 18: 1499-506

256. Kramer HF, Goodyear $\amalg$ (2007) Exercise, MAPK, and NF-kappaB signaling in skeletal muscle. J Appl Physiol 103: 388-95

257. Mourkioti F, Rosenthal N (2008) NF-kappaB signaling in skeletal muscle: prospects for intervention in muscle diseases. J Mol Med (Berl) 86: 747-59

258. Cai D, Frantz JD, Tawa NE, Jr., Melendez PA, Oh BC, Lidov HG, Hasselgren PO, Frontera WR, Lee J, Glass DJ, Shoelson SE (2004) IKKbeta/NF-kappaB activation causes severe muscle wasting in mice. Cell 119: 285-98

259. Mourkioti F, Kratsios P, Luedde T, Song YH, Delafontaine P, Adami R, Parente V, Bottinelli R, Pasparakis M, Rosenthal N (2006) Targeted ablation of IKK2 improves skeletal muscle strength, maintains mass, and promotes regeneration. J Clin Invest 116: 2945-54

260. Serrano AL, Baeza-Raja B, Perdiguero E, Jardi M, Munoz-Canoves P (2008) Interleukin-6 is an essential regulator of satellite cell-mediated skeletal muscle hypertrophy. Cell Metab 7: 3344

261. Horsley V, Jansen KM, Mills ST, Pavlath GK (2003) IL-4 acts as a myoblast recruitment factor during mammalian muscle growth. Cell 113: 483-94 
262. Chazaud B, Sonnet C, Lafuste P, Bassez G, Rimaniol AC, Poron F, Authier FJ, Dreyfus PA, Gherardi RK (2003) Satellite cells attract monocytes and use macrophages as a support to escape apoptosis and enhance muscle growth. J Cell Biol 163: 1133-43

263. St Pierre BA, Tidball JG (1994) Macrophage activation and muscle remodeling at myotendinous junctions after modifications in muscle loading. Am J Pathol 145: 1463-71

264. Tidball JG, Wehling-Henricks M (2007) Macrophages promote muscle membrane repair and muscle fibre growth and regeneration during modified muscle loading in mice in vivo. J Physiol 578: 327-36

265. Villalta SA, Deng B, Rinaldi C, Wehling-Henricks M, Tidball JG (2011) IFN-gamma promotes muscle damage in the $\mathrm{mdx}$ mouse model of Duchenne muscular dystrophy by suppressing M2 macrophage activation and inhibiting muscle cell proliferation. J Immunol 187: 5419-28

266. Villalta SA, Rinaldi C, Deng B, Liu G, Fedor B, Tidball JG (2010) Interleukin-10 reduces the pathology of $\mathrm{mdx}$ muscular dystrophy by deactivating M1 macrophages and modulating macrophage phenotype. Hum Mol Genet 20: 790-805

267. Steensberg A, van Hall G, Osada T, Sacchetti M, Saltin B, Klarlund Pedersen B (2000) Production of interleukin- 6 in contracting human skeletal muscles can account for the exercise-induced increase in plasma interleukin-6. J Physiol 529 Pt 1: 237-42

268. Pedersen BK, Febbraio MA (2008) Muscle as an endocrine organ: focus on muscle-derived interleukin-6. Physiol Rev 88: 1379-406

269. Carey AL, Steinberg GR, Macaulay SL, Thomas WG, Holmes AG, Ramm G, Prelovsek O, Hohnen-Behrens C, Watt MJ, James DE, Kemp BE, Pedersen BK, Febbraio MA (2006) Interleukin-6 increases insulin-stimulated glucose disposal in humans and glucose uptake and fatty acid oxidation in vitro via AMP-activated protein kinase. Diabetes 55: 2688-97

270. Wallenius V, Wallenius K, Ahren B, Rudling M, Carlsten H, Dickson SL, Ohlsson C, Jansson JO (2002) Interleukin-6-deficient mice develop mature-onset obesity. Nat Med 8: 75-9

271. Keller P, Penkowa M, Keller C, Steensberg A, Fischer CP, Giralt M, Hidalgo J, Pedersen BK (2005) Interleukin-6 receptor expression in contracting human skeletal muscle: regulating role of IL-6. Faseb J 19: 1181-3

272. Gleeson M (2007) Immune function in sport and exercise. J Appl Physiol 103: 693-9

273. Knowler WC, Barrett-Connor E, Fowler SE, Hamman RF, Lachin JM, Walker EA, Nathan DM (2002) Reduction in the incidence of type 2 diabetes with lifestyle intervention or metformin. N Engl J Med 346: 393-403

274. Fiatarone MA, O'Neill EF, Ryan ND, Clements KM, Solares GR, Nelson ME, Roberts SB, Kehayias JJ, Lipsitz LA, Evans WJ (1994) Exercise training and nutritional supplementation for physical frailty in very elderly people. N Engl J Med 330: 1769-75

275. Tillerson JL, Caudle WM, Reveron ME, Miller GW (2003) Exercise induces behavioral recovery and attenuates neurochemical deficits in rodent models of Parkinson's disease. Neuroscience 119: 899-911

276. Steensberg A, Fischer CP, Keller C, Moller K, Pedersen BK (2003) IL-6 enhances plasma IL-1ra, IL-10, and cortisol in humans. Am J Physiol Endocrinol Metab 285: E433-7

277. Starkie R, Ostrowski SR, Jauffred S, Febbraio M, Pedersen BK (2003) Exercise and IL-6 infusion inhibit endotoxin-induced TNF-alpha production in humans. Faseb J 17: 884-6

278. Lancaster GI, Khan Q, Drysdale P, Wallace F, Jeukendrup AE, Drayson MT, Gleeson M (2005) The physiological regulation of toll-like receptor expression and function in humans. J Physiol 563: 945-55

279. Kim MS, Shigenaga JK, Moser AH, Feingold KR, Grunfeld C (2005) Suppression of estrogenrelated receptor alpha and medium-chain acyl-coenzyme A dehydrogenase in the acutephase response. J Lipid Res 46: 2282-8

280. Feingold K, Kim MS, Shigenaga J, Moser A, Grunfeld C (2004) Altered expression of nuclear hormone receptors and coactivators in mouse heart during the acute-phase response. American journal of physiology. Endocrinology and metabolism 286: E201-7 
281. Planavila A, Sanchez RM, Merlos M, Laguna JC, Vazquez-Carrera M (2005) Atorvastatin prevents peroxisome proliferator-activated receptor gamma coactivator-1 (PGC-1) downregulation in lipopolysaccharide-stimulated H9c2 cells. Biochim Biophys Acta 1736: 1207

282. Palomer X, Alvarez-Guardia D, Rodriguez-Calvo R, Coll T, Laguna JC, Davidson MM, Chan TO, Feldman AM, Vazquez-Carrera M (2009) TNF-alpha reduces PGC-1alpha expression through NF-kappaB and p38 MAPK leading to increased glucose oxidation in a human cardiac cell model. Cardiovascular research 81: 703-12

283. Tran M, Tam D, Bardia A, Bhasin M, Rowe GC, Kher A, Zsengeller ZK, Akhavan-Sharif MR, Khankin EV, Saintgeniez M, David S, Burstein D, Karumanchi SA, Stillman IE, Arany Z, Parikh SM (2011) PGC-1alpha promotes recovery after acute kidney injury during systemic inflammation in mice. J Clin Invest 121: 4003-14

284. Sweeney TE, Suliman HB, Hollingsworth JW, Welty-Wolf KE, Piantadosi CA (2011) A toll-like receptor 2 pathway regulates the Ppargc1a/b metabolic co-activators in mice with Staphylococcal aureus sepsis. PLoS One 6: e25249

285. Menconi MJ, Arany ZP, Alamdari N, Aversa Z, Gonnella P, O'Neal P, Smith IJ, Tizio S, Hasselgren PO (2010) Sepsis and glucocorticoids downregulate the expression of the nuclear cofactor PGC-1beta in skeletal muscle. Am J Physiol Endocrinol Metab 299: E533-43

286. Feingold KR, Moser A, Patzek SM, Shigenaga JK, Grunfeld C (2009) Infection decreases fatty acid oxidation and nuclear hormone receptors in the diaphragm. J Lipid Res 50: 2055-63

287. Yu XX, Barger JL, Boyer BB, Brand MD, Pan G, Adams SH (2000) Impact of endotoxin on UCP homolog mRNA abundance, thermoregulation, and mitochondrial proton leak kinetics. American journal of physiology. Endocrinology and metabolism 279: E433-46

288. Remels AH, Gosker HR, Bakker J, Guttridge DC, Schols AM, Langen RC (2013) Regulation of skeletal muscle oxidative phenotype by classical NF-kappaB signalling. Biochim Biophys Acta

289. Coll T, Jove M, Rodriguez-Calvo R, Eyre E, Palomer X, Sanchez RM, Merlos M, Laguna JC, Vazquez-Carrera M (2006) Palmitate-mediated downregulation of peroxisome proliferatoractivated receptor-gamma coactivator 1alpha in skeletal muscle cells involves MEK1/2 and nuclear factor-kappaB activation. Diabetes 55: 2779-87

290. Zhang Y, Liu C, Zhu L, Jiang X, Chen X, Qi X, Liang X, Jin S, Zhang P, Li Q, Wang D, Liu X, Zeng K, Zhang J, Xiang Y, Zhang CY (2007) PGC-1alpha inhibits oleic acid induced proliferation and migration of rat vascular smooth muscle cells. PLoS One 2: e1137

291. Remels AH, Gosker HR, Schrauwen P, Hommelberg PP, Sliwinski P, Polkey M, Galdiz J, Wouters EF, Langen RC, Schols AM (2010) TNF-alpha impairs regulation of muscle oxidative phenotype: implications for cachexia? FASEB journal : official publication of the Federation of American Societies for Experimental Biology 24: 5052-62

292. Tang K, Wagner PD, Breen EC (2010) TNF-alpha-mediated reduction in PGC-1alpha may impair skeletal muscle function after cigarette smoke exposure. J Cell Physiol 222: 320-7

293. Remels AH, Schrauwen P, Broekhuizen R, Willems J, Kersten S, Gosker HR, Schols AM (2007) Peroxisome proliferator-activated receptor expression is reduced in skeletal muscle in COPD. The European respiratory journal : official journal of the European Society for Clinical Respiratory Physiology 30: 245-52

294. Eisele PS, Salatino S, Sobek J, Hottiger MO, Handschin C (2013) The peroxisome proliferatoractivated receptor gamma coactivator 1alpha/beta (PGC-1) coactivators repress the transcriptional activity of NF-kappaB in skeletal muscle cells. The Journal of biological chemistry 288: 6589

295. Kim HJ, Park KG, Yoo EK, Kim YH, Kim YN, Kim HS, Kim HT, Park JY, Lee KU, Jang WG, Kim JG, Kim BW, Lee IK (2007) Effects of PGC-1alpha on TNF-alpha-induced MCP-1 and VCAM-1 expression and NF-kappaB activation in human aortic smooth muscle and endothelial cells. Antioxidants \& redox signaling 9: 301-7 
296. Olesen J, Larsson S, Iversen N, Yousafzai S, Hellsten Y, Pilegaard H (2012) Skeletal muscle PGC-1alpha is required for maintaining an acute LPS-induced TNFalpha response. PLoS One 7: e32222

297. Sonoda J, Laganiere J, Mehl IR, Barish GD, Chong LW, Li X, Scheffler IE, Mock DC, Bataille AR, Robert F, Lee CH, Giguere V, Evans RM (2007) Nuclear receptor ERR alpha and coactivator PGC-1 beta are effectors of IFN-gamma-induced host defense. Genes \& development 21: 1909-20

298. Shaul ME, Bennett G, Strissel KJ, Greenberg AS, Obin MS (2010) Dynamic, M2-like remodeling phenotypes of $\mathrm{CD} 11 \mathrm{c}+$ adipose tissue macrophages during high-fat diet--induced obesity in mice. Diabetes 59: 1171-81

299. Maitra U, Singh N, Gan L, Ringwood L, Li L (2009) IRAK-1 contributes to lipopolysaccharideinduced reactive oxygen species generation in macrophages by inducing NOX-1 transcription and Rac1 activation and suppressing the expression of antioxidative enzymes. The Journal of biological chemistry 284: 35403-11

300. Ito S, Ansari P, Sakatsume M, Dickensheets H, Vazquez N, Donnelly RP, Larner AC, Finbloom DS (1999) Interleukin-10 inhibits expression of both interferon alpha- and interferon gammainduced genes by suppressing tyrosine phosphorylation of STAT1. Blood 93: 1456-63

301. Porta C, Rimoldi M, Raes G, Brys L, Ghezzi P, Di Liberto D, Dieli F, Ghisletti S, Natoli G, De Baetselier P, Mantovani A, Sica A (2009) Tolerance and M2 (alternative) macrophage polarization are related processes orchestrated by $\mathrm{p} 50$ nuclear factor kappaB. Proc Natl Acad Sci U S A 106: 14978-83

302. Liao X, Sharma N, Kapadia F, Zhou G, Lu Y, Hong H, Paruchuri K, Mahabeleshwar GH, Dalmas E, Venteclef N, Flask CA, Kim J, Doreian BW, Lu KQ, Kaestner KH, Hamik A, Clement K, Jain MK (2011) Kruppel-like factor 4 regulates macrophage polarization. J Clin Invest 121: 2736-49

303. Mahabeleshwar GH, Kawanami D, Sharma N, Takami Y, Zhou G, Shi H, Nayak L, Jeyaraj D, Grealy R, White M, McManus R, Ryan T, Leahy P, Lin Z, Haldar SM, Atkins GB, Wong HR, Lingrel JB, Jain MK (2011) The myeloid transcription factor KLF2 regulates the host response to polymicrobial infection and endotoxic shock. Immunity 34: 715-28

304. Odegaard JI, Ricardo-Gonzalez RR, Red Eagle A, Vats D, Morel CR, Goforth MH, Subramanian V, Mukundan L, Ferrante AW, Chawla A (2008) Alternative M2 activation of Kupffer cells by PPARdelta ameliorates obesity-induced insulin resistance. Cell Metab 7: 496-507

305. Suliman HB, Sweeney TE, Withers CM, Piantadosi CA (2010) Co-regulation of nuclear respiratory factor-1 by NFkappaB and CREB links LPS-induced inflammation to mitochondrial biogenesis. Journal of cell science 123: 2565-75

306. Mauro C, Leow SC, Anso E, Rocha S, Thotakura AK, Tornatore L, Moretti M, De Smaele E, Beg AA, Tergaonkar V, Chandel NS, Franzoso G (2011) NF-kappaB controls energy homeostasis and metabolic adaptation by upregulating mitochondrial respiration. Nat Cell Biol 13: 1272-9

307. Piantadosi CA, Withers CM, Bartz RR, MacGarvey NC, Fu P, Sweeney TE, Welty-Wolf KE, Suliman HB (2011) Heme oxygenase-1 couples activation of mitochondrial biogenesis to antiinflammatory cytokine expression. The Journal of biological chemistry 286: 16374-85

308. Buler M, Aatsinki SM, Skoumal R, Komka Z, Toth M, Kerkela R, Georgiadi A, Kersten S, Hakkola J (2012) Energy-sensing factors coactivator peroxisome proliferator-activated receptor gamma coactivator 1-alpha (PGC-1alpha) and AMP-activated protein kinase control expression of inflammatory mediators in liver: induction of interleukin 1 receptor antagonist. The Journal of biological chemistry 287: 1847-60

309. Bassaganya-Riera J, Reynolds K, Martino-Catt S, Cui Y, Hennighausen L, Gonzalez F, Rohrer J, Benninghoff AU, Hontecillas R (2004) Activation of PPAR gamma and delta by conjugated linoleic acid mediates protection from experimental inflammatory bowel disease. Gastroenterology 127: 777-91

310. Wang LH, Yang XY, Zhang X, Farrar WL (2007) Inhibition of adhesive interaction between multiple myeloma and bone marrow stromal cells by PPARgamma cross talk with NF-kappaB and C/EBP. Blood 110: 4373-84 
311. Morari J, Torsoni AS, Anhe GF, Roman EA, Cintra DE, Ward LS, Bordin S, Velloso LA (2010) The role of proliferator-activated receptor gamma coactivator-1alpha in the fatty-acid-dependent transcriptional control of interleukin-10 in hepatic cells of rodents. Metabolism: clinical and experimental 59: 215-23

312. Alvarez-Guardia D, Palomer X, Coll T, Davidson MM, Chan TO, Feldman AM, Laguna JC, Vazquez-Carrera M (2010) The p65 subunit of NF-kappaB binds to PGC-1alpha, linking inflammation and metabolic disturbances in cardiac cells. Cardiovascular research 87: 449-58

313. Liang H, Balas B, Tantiwong P, Dube J, Goodpaster BH, O'Doherty RM, DeFronzo RA, Richardson A, Musi N, Ward WF (2009) Whole body overexpression of PGC-1alpha has opposite effects on hepatic and muscle insulin sensitivity. American journal of physiology. Endocrinology and metabolism 296: E945-54

314. Yang J, Williams RS, Kelly DP (2009) Bcl3 interacts cooperatively with peroxisome proliferator-activated receptor gamma (PPARgamma) coactivator 1alpha to coactivate nuclear receptors estrogen-related receptor alpha and PPARalpha. Molecular and cellular biology 29: 4091-102

315. Fink LN, Oberbach A, Costford SR, Chan KL, Sams A, Bluher M, Klip A (2013) Expression of anti-inflammatory macrophage genes within skeletal muscle correlates with insulin sensitivity in human obesity and type 2 diabetes. Diabetologia 56: 1623-8

316. Fink LN, Costford SR, Lee YS, Jensen TE, Bilan PJ, Oberbach A, Bluher M, Olefsky JM, Sams A, Klip A (2013) Pro-Inflammatory macrophages increase in skeletal muscle of high fat-Fed mice and correlate with metabolic risk markers in humans. Obesity

317. Ikeda SI, Tamura Y, Kakehi S, Takeno K, Kawaguchi M, Watanabe T, Sato F, Ogihara T, Kanazawa A, Fujitani Y, Kawamori R, Watada H (2013) Exercise-induced enhancement of insulin sensitivity is associated with accumulation of M2-polarized macrophages in mouse skeletal muscle. Biochem Biophys Res Commun

318. Sadana P, Park EA (2007) Characterization of the transactivation domain in the peroxisomeproliferator-activated receptor gamma co-activator (PGC-1). Biochem J 403: 511-8 


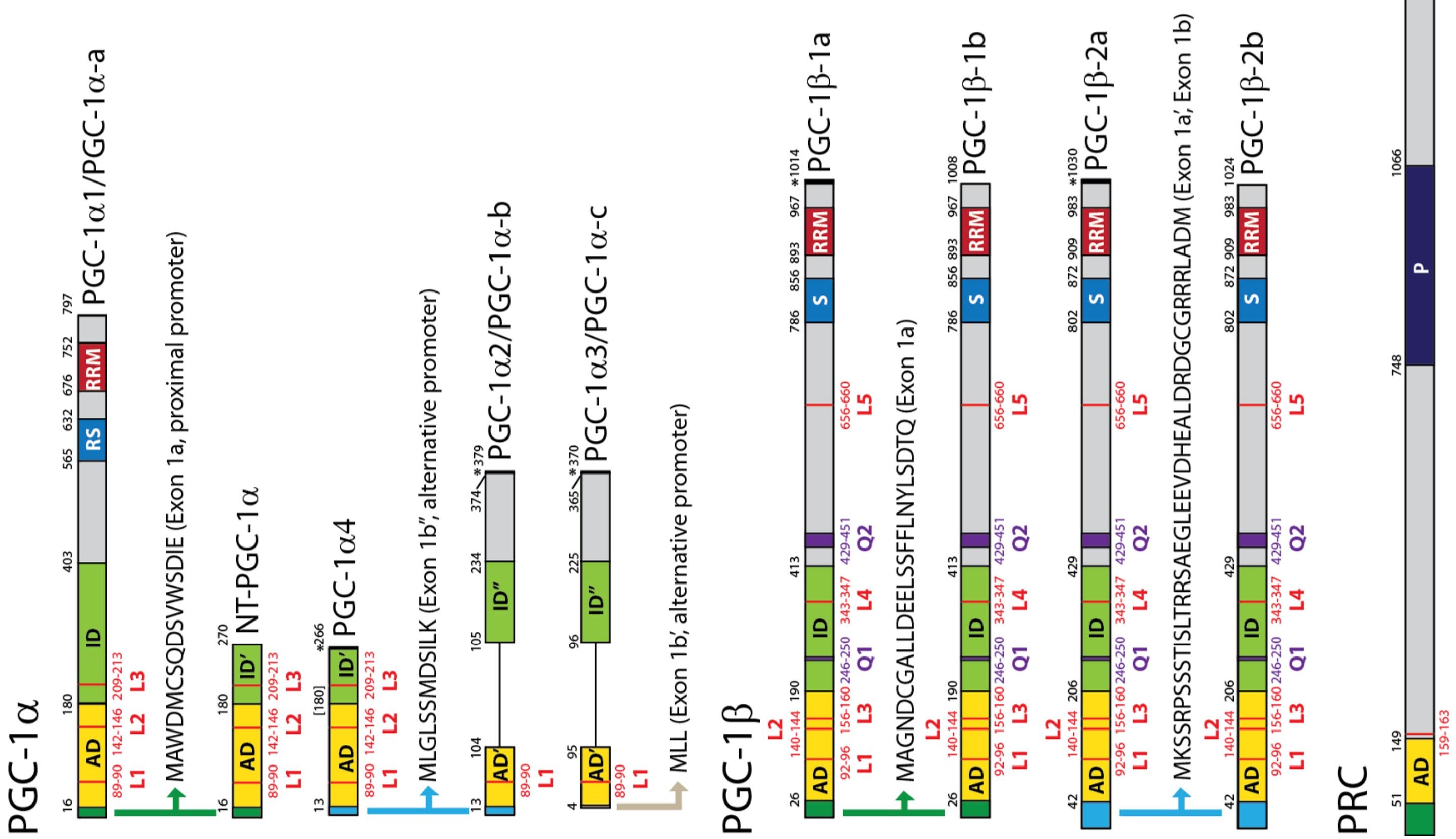


A

oxidative metabolism
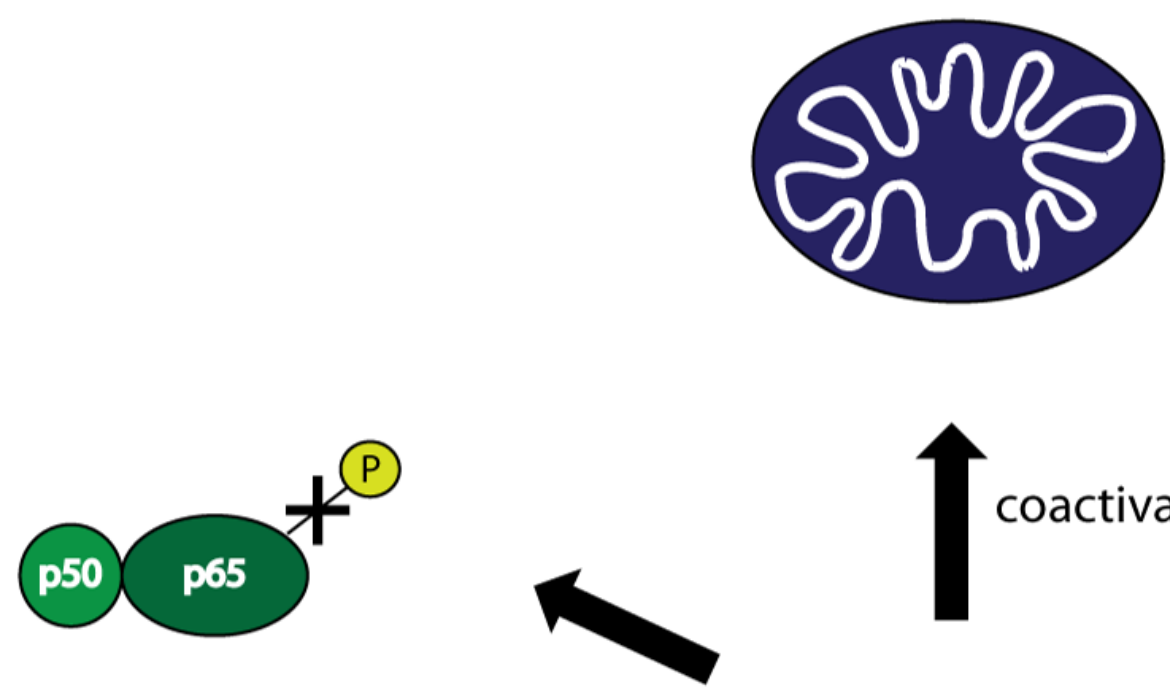

inhibition of

phosphorylation

I
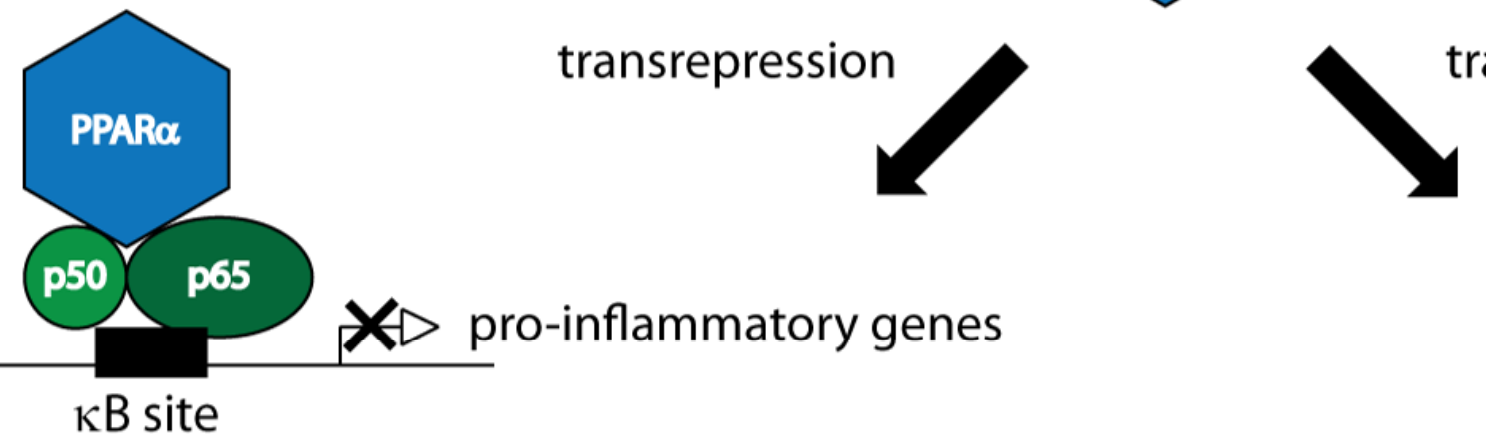

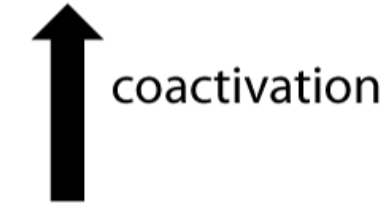

B
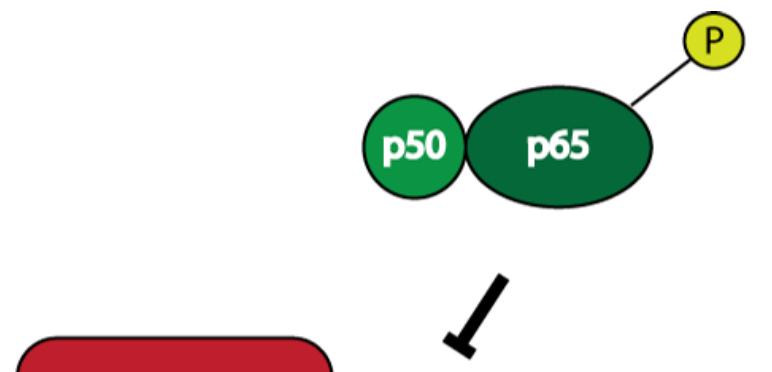

\section{PGC-1}

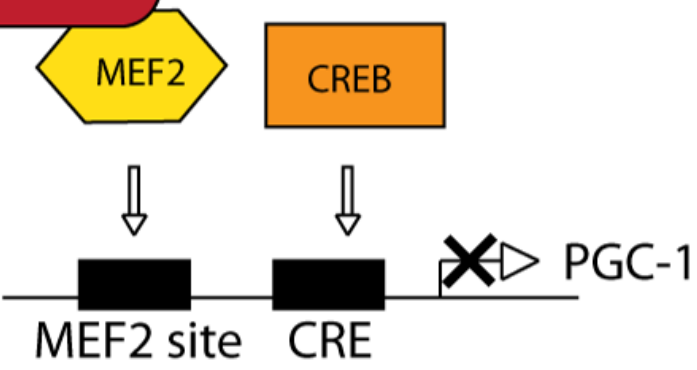

PGC-1

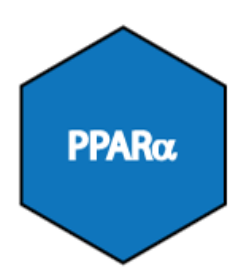

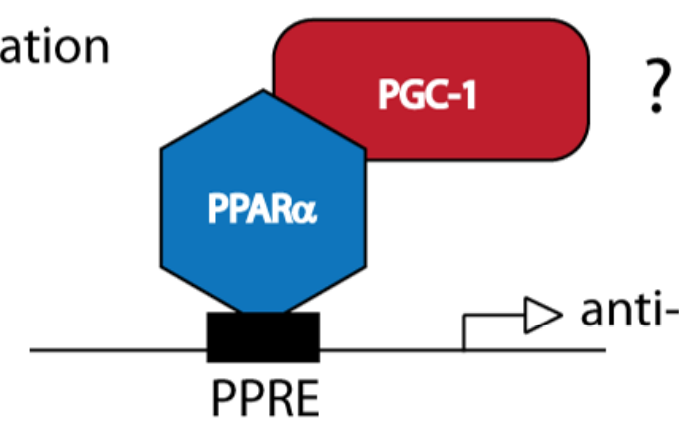



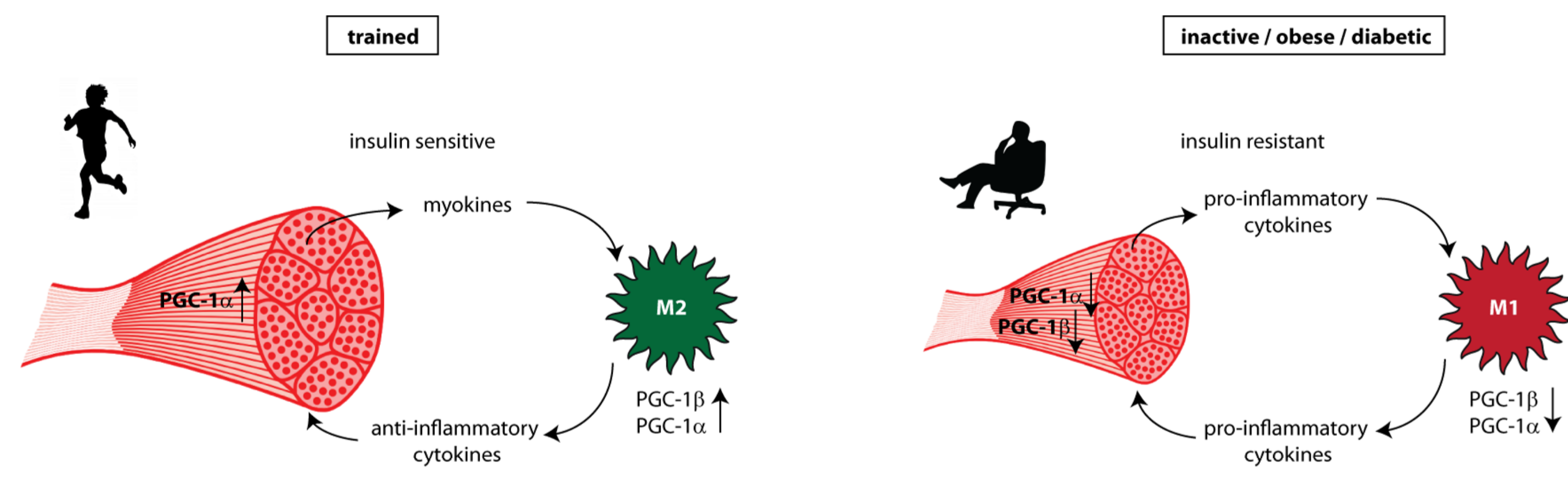